\title{
IDEA DE LA HISTORIA Y PROYECTO ICONOGRÁFICO EN LA ANACEPHALEOSIS DE ALONSO DE CARTAGENA ${ }^{1}$
}

\author{
IDEA OF HISTORY AND ICONOGRAPHIC PROJECT: \\ ALONSO DE CARTAGENA'S "ANACEPHALEOSIS"
}

\author{
LUIS FERNÁNDEZ GALLARDO \\ Universidad Nacional de Educación a Distancia
}

\begin{abstract}
Resumen: Alonso de Cartagena (13851456) escribió "motu proprio" la Genealogía de los reyes de España. Su composición fue discontinua. Fue dedicada primeramente a Juan II, pero al morir éste, acabó dedicada al cabildo burgalés, pues no interesó al sucesor Enrique IV. En el prólogo se introducen tópicos humanísticos y se justifica la doble naturaleza, verbal e icónica, de la obra en el marco de la teoría mnemotécnica del Medievo. Don Alonso construye un riguroso sistema icónico, que combina vestimenta, atributos y gestos, para ofrecer una imagen de la realeza castellana que exalta la "fortitudo", la virtud axial orientada hacia la lucha contra los moros, que para él constituye la misión propia de la monarquía hispana.
\end{abstract}

Palabras clave: Alonso de Cartagena; Castilla; Siglo XV; Historiografía; Genealogía; Iconografía; Realeza.

\begin{abstract}
Alonso of Cartagena (13851456) wrote "motu proprio" the Genealogía de los reyes de España. However, the writing process itself was discontinous. First, it was meant for King John II (1454). But after his dead, it ended as dedicated to the chapter of Burgos (1456), because it was disregarded by King Henry IV. In the Preface he develops humanistic topics and justifies the double nature of his work by means of the medieval mnemotecnic theory. Don Alonso produced a rigorous iconic system. It combines clothing, attributes and gestures, to provide a picture of castilian royalty, that praises the "fortitudo". This fundamental virtue is aimed at enhancing the war against the Moors, which is thought as the proper commitment of the Hispanic Monarchy.

Keywords: Alonso of Cartagena; Castile; 15th century; Historiography; Genealogy; Iconography; Kingship.
\end{abstract}

\section{SUMARIO}

I. El proyecto historial de Alonso de Cartagena. 1. Génesis de la obra. 2. Una reflexión sobre el saber histórico. 3. El género: entre la genealogía y la historia.- II. El elemento icónico: 1. Justificación. De teoría mnemotécnica. 2. Plan general de la serie icónica. 3. Imagen y glosa.III. El sistema iconográfico: 1. Las variables. 2. El atuendo bélico o la expresión de la fortitudo. 3. El atuendo pacífico. 4. Referencias a la edad. 5. La muerte violenta. 6. La imagen descriptiva y narrativa.- IV Imágenes de la realeza.

${ }^{1}$ Este trabajo forma parte del Proyecto de Investigación "Las relaciones de conflicto en sus prácticas representativas. La Corona de Castilla en su contexto europeo, siglos XIII-XV" Proyecto HUM 2006-05233/HIST, del Ministerio de Educación y Ciencia, que dirige el Prof. José Manuel Nieto Soria, de la Universidad Complutense de Madrid. 


\section{El PROYECTO HiStorial DE Alonso DE CARTAGENA}

\section{Génesis de la obra}

No deja de ser paradójica la accidentada génesis de la Anacephaleosis: una de las pocas obras que Alonso de Cartagena compuso "motu proprio" tuvo serias dificultades para hallar destinatario. Quien escribió la casi totalidad de una considerable producción literaria a instancias de insistentes peticionarios hubo de ver frustradas sus expectativas de reconocimiento en los círculos cortesanos a propósito de una obra que precisamente compendiaba su dilatada labor como ideólogo y publicista al servicio de la realeza castellana.

Como es habitual en sus prólogos, don Alonso da en el de su Genealogía detallada cuenta de las circunstancias de su composición ${ }^{2}$. La obra fue concebida en principio como ofrenda historial con que pretendía satisfacer los afanes intelectuales del rey Juan II. La referencia a la utilidad del saber histórico en determinadas ocasiones, cuando la conversación -o el debaterequiere la alegación de datos históricos ${ }^{3}$, tal vez apunte al origen de la iniciativa de escribir una obra de tales características: ¿diálogos cortesanos en que el rey sugeriría la necesidad de una obra que reuniera los datos esenciales sobre la historia hispana? Un significativo indicio de los intereses culturales de los círculos cortesanos lo ofrece la serie de cuestiones que le planteó a Cartagena su amigo Fernán Pérez de Guzmán y cuya cumplida respuesta constituye el Duodenarium: cuestiones como quién fue el rey hispano más virtuoso o sobre la prelación de las dignidades imperial y real, que exigían una argumentación histórica. Es posible que ante una sugerencia como la apuntada respondiera solícito el obispo de Burgos. Una obra de su amigo Pier Candido Decembrio, con quien mantenía una intensa relación epistolar, pudo inspirarle, a su vez, la posibilidad de una ofrenda historial para el rey castellano. En efecto, el humanista milanés había compuesto en 1442 para Alfonso V de Aragón un Compendium historiae romanae: listas de reyes, cónsules, guerras y campos de batalla, extractadas de Floro ${ }^{4}$. Las consideraciones de la carta nuncupatoria, con su insistencia en la facilidad del texto para su memorización y lo esquemático de los contenidos abona la posibilidad

${ }^{2}$ Preciso y matizo las ideas expuestas al respecto en Luis FernÁNDEZ GALLARDO, La obra historiográfica de dos conversos ilustres, don Pablo de Santa María y don Alonso de Cartagena "Espacio, Tiempo y Forma" (Serie III), VI (1993), pp 249-286 y, sobre todo, Alonso de Cartagena (1385-1456). Una biografía polititica en la Castilla del siglo ẊV, Valladolid, 2002 $\mathrm{pp}$. 280-282, especialmente a la vista de la detenida y concienzuda crítica que del primer trabajo hace Robert FOLGER, Generaciones y semblanzas. Memory and Genealogy in Medieval lberian Historiography, Tubinga, 2003, pp. 147-152.

3،... libellum aliquem tenere qui haec sub breui compendio co(n)tineat, vt cum sermo de huiuscemodi rebus occurrerit, aliqualem cognitionem apprehendere valeamus" [Alonso de CARTAGENA, Anacephaleosis, Praefatio, in Rerum Hispanicarum Scriptores aliquot ex Bibliotheca Roberti Beli (R. BELL, ed.), Francfurt, 1579, p. 611].

${ }^{4}$ Ludwig BERTALOT, Pier Candido Decembrio der Verfasser von Pseudo-Boccaccios "Compendium Historiae Romanae» (1911), in Studien zum italienischen und deutschen Humanismus (P.O. KRISTELLER, ed.), 1975, I, pp. 207-211 (transcripción de la dedicatoria en pp. 208-209). 
de que le sirviera de modelo a Cartagena cuando éste decide complacer al rey castellano en su avidez de conocimientos históricos.

Don Alonso envió al rey Juan II un avance de su obra ${ }^{5}$. No queda del todo claro si el término "particula" para designar la parte remitida se refiere al primero de los componentes en que estructuró originariamente su obra o bien simplemente una muestra. Otros interrogantes igualmente sustanciales plantea esta primera entrega: ¿se envió solo el texto o junto con él las imágenes que formaban el árbol genealógico? De aceptarse la segunda opción, es obvio que Cartagena controlaría la efectiva elaboración del aparato iconográfico, aunque por las razones que más abajo se exponen creemos que la muestra remitida iría desprovista de imágenes. En cualquier caso, la muerte del monarca interrumpió la redacción de la Genealogía. La composición de esta primera parte tuvo lugar, por tanto, poco ante del óbito regio (21 de julio de 1454), esto es, a comienzos del verano de ese año. La desaparición del dedicatario de la Genealogía supuso la interrupción de su redacción, a la espera de su reanudación -que habría de obedecer a la demanda del nuevo monarca- ya fuese por el mismo autor o, concesión a la modestia ingénita de don Alonso, si no es que sentía que dada su provecta edad le faltaban fuerzas para tal empeño, por otro de más elevado ingenio.

Entretanto, Cartagena decidió dar una nueva orientación al proyecto original: elaborar una versión más breve que lo concebido en un principio. Para dar cuenta de ello recurre hábilmente a una imagen agrícola: pues se trataba de un árbol genealógico, el nuevo proyecto se concibe como un trasplante. Puesto que la justificación de esta modificación reitera el argumento con que se avalaba la elección de la forma del árbol genealógico según la idea original, cabe plantear si la decisión de tal cambio no obedecería a la necesidad de reajustar las dimensiones del texto para su conjunción con el aparato icónico. Según esta suposición, lo que don Alonso envió al rey Juan II como muestra habría sido aquella sección de la historia hispana anterior a la institución de la monarquía, que en la versión latina impresa abarca los siete primeros capítulos. Y efecivamente, este tramo de la obra se ajusta perfectamente a la expresión con que la designó el propio autor ("particula prima") 6 .

5 “... particula prima suae Regiae maiestati tradita...” (Anacephaleosis, Praefatio, p. 611). El tenor literal del texto avala esta interpretación antes que la suposición de que se refiere a un "draft of a historical work" (R. FOLGER, Generaciones, p. 151). Cumplida presentación de la tradición textual de esta obra, análisis de sus testimonios manuscritos e impresos, en Elișa RUIZ GARCÍA, Avatares codicológicos de la Genealogía de los Reyes de España, "Historia. Instituciones. Documentos", 27 (2000), pp. 299-304. Utilizamos la denominación de los testimonios manuscritos que se ofrece en este trabajo (p. 323).

${ }^{6}$ Anacephaleosis, pp. 613-621. El final del capítulo VII marca una divisoria en el conjunto de la obra al indicar que lo narrado era suficiente y al introducir el aparato icónico: "Haec ad intelligentiam dicendorum praemisisse sufficiat, \& iam quod mente concepimus, exequamur, \& ex deuotis praecordiis omnipotentis Dei iterata deprecatione suffragio implorato, Reges ipsos, prout temporum suorum ordo deposcit, huic arbori inseramus" (Anacephaleosis, cap. VII, p. 621). De hecho, en los manuscritos latinos más tempranos, la capitulación se aplica únicamente a este tramo de la obra (AHN, cód. 983 B, ff. 6 v. y 8 r.; BNM, ms. 13260 , ff. 5 r. y 6 r.). Ciertamente, tal argumento no es una certezá, pero sí una posibilidạd avalada por razones de tipo textual. De ahí que sea una actitud hipercrítica negar dicha posibilidad (inferir lo que envió don Alonso al rey) (R. FOLGER, Generaciones, p. 150). 
Solo cuando decidió proseguir la obra proyectada, se percataría el autor de la dificultad de ensamblar imagen y texto conforme a las pautas expositivas que se había fijado: un término medio entre la prolijidad narrativa de la historia y la brevedad extrema propia de los árboles genealógicos. Se le impuso entonces dar una vuelta más de tuerca en la operación de extractar o resumir las fuentes allegadas. Tras referir los avatares que sufrió el texto, la modificación del proyecto original, Cartagena se extiende en diversas consideraciones sobre el plan iconográfico (la jerarquización de los personajes representados mediante su distribución en el espacio material del texto y la modalidad del retrato, cuerpo entero únicamente para los reyes y busto para destacadas personalidades no regias) y las series de "concurrentia" incluidas.

Y a continuación incluye la dedicatoria, dirigida al cabildo burgalés, con lo que se produce un brusco tránsito desde los círculos palatinos en los que se había movido el proyecto original a la clerecía de Burgos -ciertamente mitigado por la referencia a los últimos "concurrentia", la serie de obispos burgaleses, que marca la transición de la justificación de algunas propiedades formales a la dedicatoria. El hiato que se observa entre el ambiente palaciego y el clerical delata la búsqueda de un nuevo destinatario, que no se explica sino por el escaso o nulo interés que el proyecto historiográfico suscitó en el nuevo monarca y en su entorno.

Cabe plantearse cuál fue la realidad textual que no halló el eco esperado en la corte de Enrique IV. Que no se corresponde con el texto definitivo está fuera de duda: la inclusión de la serie de prelados burgaleses como "concurrentia", que difícilmente se justificaría si la obra no estuviera dedicada al cabildo -pues resultaba extemporánea en una obra de intensa inspiración monárquica-, hubo de añadirse tras el cambio de dedicatario. Una mayor precisión al respecto no es sino materia de especulación.

La accidentada génesis de la Genealogía de los reyes de España puede, por tanto, presentarse del modo siguiente. Tal vez ante la sugerencia del rey Juan II de la necesidad de una obra histórica de cómoda consulta, Alonso de Cartagena decidió componer una genealogía de la casa real castellana. Lo novedoso del proyecto en Castilla residía en la integración de imagen y texto, característica, por su parte, del género genealógico, lo cual, a su vez, exigía suma brevedad en la exposición de los contenidos. A comienzos del verano de 1454, Cartagena le presentó al rey Juan II un avance de su obra. Mas la muerte del monarca interrumpió su redacción. Entretanto, se le ocurrió al autor modificar la idea original, procurando una mayor brevedad, tal vez compelido por la necesidad de ajustar el texto al marco icónico. Puesto que la obra no obtuvo el esperado reconocimiento en el nuevo entorno cortesano -no sería improbable que su autor la ofreciera al sucesor en la corona Enrique IV-, don Alonso decidió dedicarla al cabildo de Burgos. De ahí la incorporación de la serie de prelados burgaleses, que imprime un sesgo 
local a la obra. El texto es fechado con precisión en el epílogo: 28 de febrero de 1456, límite de los hechos narrados .

Por tanto cabe establecer tres fases en su elaboración, a las que corresponderían tres estadios textuales. La primera constituye el inicio del proyecto original: una genealogía de la casa real castellana, que combinaba texto e imagen. Su representante textual fue el avance presentado al rey Juan II, a comienzos del verano de 1454, cuyos límites son puramente conjeturales; tal vez la parte a la que no corresponden ilustraciones, los siete primeros capítulos que contienen la prehistoria de la monarquía hispana, esto es, la historia anterior al rey Atanarico. Una segunda se halla representada por la reanudación del proyecto, que, a su vez, ha sufrido una modificación, consistente en la constitución de un texto aún más breve. La tercera correspondería al texto definitivo, resultado de añadir la serie de prelados burgaleses entre los "concurrentia", el epílogo, que reafirma la dedicatoria al cabildo burgalés, y el prólogo -o su reelaboración.

\section{Una reflexión sobre el saber histórico}

Dicho prólogo contiene una acabada exposición de las ideas de Alonso de Cartagena sobre de la historia, que resultan especialmente notables por el riguroso planteamiento intelectual en que se basan. La originalidad de su proyecto historiográfico no se explica plenamente sino desde la perspectiva de sus ideas acerca del saber histórico. Frente a la tradición prologal que instaura el prefacio compuesto por Rodrigo Jiménez de Rada para su De rebus Hispaniae, vertebrado en torno a la concepción de la historia como escritura que conserva la memoria de las hazañas pretéritas ${ }^{8}$, el obispo de Burgos, sin dejar de sentir reverencia por la obra del Toledano, sigue un derrotero bien distinto. Frente a la trillada ponderación de las propiedades de la escritura, sitúa sus consideraciones sobre la historia en el marco de un planteamiento epistemológico: el análisis de su posición en el sistema de las ciencias.

${ }^{7}$ Anacephaleosis, p. 664.

${ }^{8}$ Rodrigo JimÉnEZ DE RADA, De rebus Hispaniae, Praefatio, PP. Toletanorum quotquot extant Opera, t. III, Madrid, 1792,pp. 1-2. Analizado en Luis FERNÂNDEZ GALLARDO, De Lucas de Tuy a Alfonso el Sabio: idea de la historia y proyecto historiográfico, "Revista de Poética Medieval", 12 (2004) pp. 67-78. Adquiere rango canónico al ser traducido en la Estoria de España de 'Alfonso X el Sabio (Primera Crónica General de España (R. MENÉNDEZ PIDAL, ed.), Madrid, $1977^{2}$, t. I, pp. 3-4). Para la difusión de la obra de Jiménez de Rada a través de sus romanceamientos, véase Diego CATALÁN, "Rodericus" romanzado en los reinos de Aragón, Castilla y Navarra, Madrid, 2005. Se mantiene el planteo del Toledano hasta Pérez de Ayala, quien en el prólogo a sus cronicas vuelva a desarrollar el tópico de la escritura como depósito de la memoria [Crónicas, Proemio (J. L. MARTín, ed.), Barcelona, 1991, p. 3]. De la virtualidad canónica de dicho planteamiento ofrece un elocuente testimonio el prólogo de la crónica que continuaba la obra de Pérez de Ayala: "E por quanto en las arengas e prólogos que los estoriadores pasados de las dichas Corónicas fizieron en ellas está contenido, asaz e muy complidamente hordenado e tratado, lo que conviene e de razón se requiere al comienco e entrada de las dichas Corónicas, por ende el nuevo estoriador entra en la orden..." [Alvar GARCÍA DE SANTA MARÎA, Crónica de Juan II de Castilla (J. de M. CARRIAZO ed.), Madrid, 1982, pp. 4-5]. Así, el cronista y consejero de Juan II se remite a la tradición firmemente establecida por el Toledano como si de principios universalmente admitidos se tratara. 
El punto de partida es un tópico aristotélico que aparece recurrentemente en la obra de Cartagena: la frase inicial de la Metafísica, que afirma la esencial vocación cognitiva del hombre. Ahora bien, a diferencia de las otras ocasiones en que lo utiliza ${ }^{9}$, en la Genealogía ofrece una muy elaborada presentación, en la que se trenzan resonancias ciceronianas y bíblicas. En primer lugar, como ya señaló Elisa Ruiz, el arranque del prólogo es similar al de De oratore ${ }^{10}$. En efecto, don Alonso parece tener en mente el comienzo del tratado ciceroniano cuando reproduce no solo la estructura de la frase inicial, sino incluso sintagmas en su tenor litera ${ }^{11}$. El obispo de Burgos se hallaba familiarizado con las obras de Cicerón; tradujo algunas durante su misión diplomática en Portugal (1421-1427), entre ellas, la Rhetorica ad Herennium para el príncipe portugués don Duarte, entre 1425 y 1431. Mas lo significativo de esta cita es que el Cicerón invocado no es ya el de la tradición retórica medieval, sino el que los nuevos hallazgos humanísticos desvelaban: precisamente el descubrimiento de un manuscrito completo de De oratore en Lodi, en 1421, contribuyó a que la imagen del Cicerón moralista diera paso a la del hombre comprometido en los conflictos políticos ${ }^{12}$. Tanto más que el eco verbal es de destacar el contenido del "locus" ciceroniano. Así, las palabras tomadas de De oratore constituyen nada menos que el molde verbal de una de las ideas centrales del pensamiento ciceroniano: la integración de la vida activa y contemplativa en un mismo proyecto vital, que se lleva a cabo por medio del concepto de otium $^{13}$. Precisamente ese descubrimiento de la dimensión de la faceta pública de Cicerón, del hombre comprometido en las lizas políticas de su tiempo permitirá superar la incompatibilidad que para el estamento caballeresco era sentida en Castilla entre vocación de las armas y cultivo de las letras. No es un hecho carente de significación el que Cartagena avale la pertinencia del conocimiento histórico con una tácita apelación al nuevo ideal humano encarnado en la figura del orador, en la que los

${ }^{9}$ Alonso de CARTAGEnA (trad.), De la providencia de Dios, BNM, ms. 5568, f. 50 r.-v.; A. de CARTAGENA, Epistula directa ad inclitum et magnificum virum dominum Petrum Fernandi de Velasco, Comitem de Haro, apud Jeremy H.N. LAWRENCE, Una epístola de Alonso de Cartagena sobre la educación y los estudios literarios, Barcelona, 1979, pp. 31-32.

${ }^{10}$ E. Ruiz GARCíA, Avatares codicológicos, p. 296.

11 "Cogitanti mihi fratres dilectissimi, \& freque(n)ter in animo reuoluenti, quantum sit humanis animis scie(n)di infixa cupido, vt [...] omnis homo a natura scire desideret, quatenus hominem exuere videatur..." (Anacephaleosis, Praefatio, p. 611): "Cogitanti mihi saepe numero et memoria vetera repetenti perbeati fuisse, Quinte frater, illi videri solent, qui in optima re publica [...] eum vitae cursum tenere potuerunt, ut vel in negotio sine periculo vel in otio cum dignitate esse possent..." (Cicerón, De oratore, I, 1). Cfr. ARISTÓTELES, Metafísica, I, 1, 980a, trad. T. Calvo Martínęz, Madrid, 1994, p. 69.' No es un hecho irrelevante el que dicha cita sea la primera del florilegio de sentencias de Aristóteles que tuvo una circulación muy intensa en el Medievo (Auctoritates Aristotelis, § 1, ápud Jacqueline HAMESSE, Les Auctoritates Aristotelis. Un Florilège médiéval. Etude historique et édition critique, Lovaina-París, 1974, p. 115). Para la presencia en España de dicho florilegio, véase Iñigo RUIZ ARZÁLLUZ, El mundo intelectual del 'antiguo autor': las Auctoritates Aristotelis en la Celestina primitiva, "Boletín de la Real Academia Españ்la", LXXVI (1996), pp. 265-282 (especialmente 269).

${ }^{12}$ Walter RÜEGG, Cicero in Mittelalter und Humanismus, in Lexikon des Mittelalters, t. II, Múnich-Zúrich, 1983, col. 2065.

${ }^{13}$ Para la noción de otium, véase Charles WIRSZUBSKI, Cicero's Cum Dignitate Otium, "Journal of Roman Studies", 44 (1954), pp. 1-13; J.P.V.D.' BALDSON, Auctoritas, Dignitas, Otium, "Classical Quarterly", X (1960), pp. 43-50. 
humanistas proyectaron sus aspiraciones a al reconocimiento y el liderazgo social $^{14}$.

Ahora bien, como si sintiera don Alonso la necesidad de compensar el sesgo clasicista -o paganizante- del desarrollo del tópico aristotélico, incluye asimismo una cita bíblica: la recriminación veterotestamental de la ignorancia sacerdotal se transfiere para remachar la esencial vocación cognitiva del hombre ${ }^{15}$. De este modo, el tópico aristotélico se presenta engastado en sendas citas de la Antigüedad y la Biblia, que dan la sensación de un calculado equilibrio de referentes culturales, tal vez condicionado por las cautelas de que había de cubrirse el optimismo intelectual que caracteriza el pensamiento de Alonso de Cartagena, ante la ofensiva que contra los conversos se había lanzado desde muy poderosos círculos. Aunque el locus aristotélico expresa hondas convicciones del prelado burgalés, que están en la base de su vocación estudiosa, no hay que perder de vista que constituía un tópico ampliamente difundido con que se justificaban muy distintos saberes: aparece precisamente abriendo el prólogo de la General Estoria de Alfonso el Sabio ${ }^{16}$. Es probable, empero, que la idea de recurrir a él le viniera sugerida por el ejemplo del prefacio que su amigo el humanista Leonardo Bruni puso al frente de su De bello italico adversus Gothos ${ }^{17}$.

Como es habitual en los prólogos de Cartagena, el de la Genealogía adquiere un sesgo epistolar en la medida en que se halla presente el destinatario en segunda persona -el cabildo burgalés-, estableciéndose así el cauce comunicativo propio de esta modalidad de escritura. Desde esta perspectiva, la cita aristotélica adquiere una precisa función: se subordina a las estrategias retóricas del exordium, para el que las artes dictaminis prescribían la apelación a una autoridad que se citaba como argumento de las consideraciones que se desarrollaban. Don Alonso no utiliza el tópico como mero material de acarreo tradicional, sino que se inserta en una construcción argumentativa sobre la que se alza una muy original reflexión acerca del saber histórico.

La proclamación de la esencial vocación cognitiva del hombre viene a ser el marco de una consideración del estatuto epistemológico de la historia. Así, se traza en primer lugar un breve esquema de los distintos tipos de ciencias, para destacar los múltiples ambitos en que puede ejercitarse el afán de saber. Para abarcar todos los tipos de conocimiento, Cartagena se refiere

\footnotetext{
${ }^{14}$ Véanse al respecto las sugestivas reflexiones de O.B. HARDISON, The Orator and the Poet: The Dilemma of Humanist Literature, "Journal of Medieval and Renaissance Studies", 1 (1971), pp. 33-44.

${ }^{15}$ “Cogitanti mihi $[\ldots]$ quantum [...] \& illius repulsionis dignus haberi merito debeat: Tu scientiam repulisti, \& ego te repellam: dulcedo quaedam me(n)tis aduenit" (Anacephaleosis, Praefatio, p. 611): "Conticuit populus meus, eo quod non habuerit scientiam. Quia tu scientiam repulisti, repellam te, ne sacerdotio fungaris mihı" (Osee, 4, 6).

${ }^{16}$ General Estoria, Prólogo (P. SÁnchez-Prieto BorJa, ed.), Madrid, 2001, t. I, p. 5. Véase L. FERNÁNDEZ GALLARDO, De Lucas de Tuy, p. 91.

${ }^{17}$ Como ya quedó apuntado en L. FERNÁNDEZ GALLARDO, La obra historiográfica, p. 273.
} 
a "ciencias" y "artes" 18 . Bajo este último término, antes que al sistema de las artes liberales, más bien se refiere al tipo de saber no formalizado en el sistema escolástico. Una intensa inspiración tomista preside las notas de epistemología en que se enmarca su reflexión sobre la historia: la distinción entre los saberes que versan sobre lo necesario y entre los que tratan de lo contingente deriva del planteo de Santo Tomás, cuyos términos filosóficos ("necessariis", "contingentibus") son brevemente glosados ${ }^{19}$, como si sintiera don Alonso la necesidad de aclarar tecnicismos de letrado a un lector lego, indicio éste de que el prólogo, al menos el tramo en cuestión, tal vez se redactara cuando aún pensaba en un dedicatario regio. Una leve precisión establece en lo concerniente a la diversidad de las vocaciones hacia el saber, al distinguir entre quienes se dedican "ad scientifica" y "ad aliquas alias disciplinas", a la vez que apostilla los asuntos científicos, indicando sus contenidos: "naturalia" y "supra naturam" 20 . Dicho esquema viene a ser una presentación simplificada de la clasificación de las ciencias que elaboró Casiodoro partiendo del sistema establecido por Boecio y tuvo una amplia difusión merced a una probable recensión popular del siglo VII que se atribuyó a Aristóteles. Según ésta la filosofía se divide en dos grandes ramas: teorética y práctica. La primera, a su vez, en divina, doctrinal (que incluye las cuatro disciplinas del quadrivium) y natural ${ }^{21}$. El término disciplina hay que considerarlo como sinónimo de scientia. Por tanto, esas "otras disciplinas" remiten a las ciencias de carácter práctico (ética, política...) Así, la distinción que hace Cartagena entre scientiae y disciplinae correspondería a la que Aristóteles estebleció entre ciencias especulativas y ciencias prácticas; las primeras tiene por fin la verdad, las segundas la acción ${ }^{22}$.

Una vez presentada la amplia panorámica del saber humano, el docto prelado burgalés no se sirve de ella para definir la situación epistemológica de la historia, entre otras cosas, porque ni la tradición clásica ni el sistema escolástico le asignaban lugar alguno en el sistema de las ciencias. Más bien,

18“... cu(m) infinita pene scientiarum \& artium sit multitudo..." (Anacephaleosis, Praefatio, p. 61). Äunque la observación es ciertamente trivial, tal vez refleje el recuerdo de ARISTÓTELES, Etica Nicomáquea, 1094a, trad. J. Pallí Bonet, Madrid, 1988, p. 129: “... como hay muchas acciones, artes y ciencias..." Es de destacar cómo la multitud de saberes que reconoce el Estagirita se dilata hasta casi la infinitud que proclama el obispo de Burgos. Esa conciencia de lo ilimitado del saber humano se plasma, a su vez, en la conciencia de la asimismo infinita serie de textos que versan sobre las diferentes disciplinas. En el Memoriale virtutum, su primera obra original (ca. 1425), presenta este motivo un interesante desarrollo -apostillado con un cita bíbliça, que ofrece un paralelismo verbal con el pasaje de la Genealogía mencionado: "Nam licet infinita pene est multitudo libro(rum) qui de moribus tractat..." (A. de CARTAGENA, Memoriale virtutum, BNM, ms. 9178, f. 2 v.).

19 “...cu(m) infinita pene scientiarum \& artium sit multitudo, quarum aliquae de necessariis naturae, quorum directio humano iudicio non subest, aliae vero in contingentibus occupantur, quae aliter \& aliter interdum eueniu(n)t..." (Anacephaleosis, Praefatio, p. 611): "Si autem attendantur ipsae res, sic quaedam scientia est de necessariis, quaedam vero de contingentibus" (SANTO TOMÁs DE AQUINO, Summa Theologiae, 1, q. 86, a. 3).

20"Alii ad scientifica, \& naturalia, \& supra naturam: alii vero ad aliquas disciplinas vehementius inclinantur..." (Anacephaleosis, Praefatio, p. 611).

${ }^{21}$ James A. WEISHEIPL, Classification of the Sciences in Medieval Thought, "Mediaeval Studies", XXVII (1965), pp. 62-63.

${ }^{22}$ ARISTÓTELES, Metafísica, 993b, p. El locus correspondiente figuraba en el florilegio mencionado (Auctoritates Aristotelis, \$39, p. 118). 
dado que dicha panorámica se subordinaba a la consideración de los diferentes temples intelectuales de los hombres, procede a indicar el tipo de capacidades que requiere el saber histórico. $\mathrm{Y}$ en este punto, don Alonso desliza una observación en que se expresa su más genuina estimación de la historia: ésta no requiere precisamente ni ingenio ni capacidad elevados, aunque, eso sí, requiera unas aptitudes más que medianas ${ }^{23}$. Aquí se expresa el jurista ufano de su ciencia, que contempla de modo condescendiente una disciplina que permanecía al margen de la sistematización escolástica. Tal vez en esta observación se manifieste de manera tácita su posición frente a la revalorización de la historia que estaban llevando a cabo los humanistas sobre fundamentos retóricos ${ }^{24}$. Quien alzara su voz alertada ante el empeño de los humanistas de unir ciencia y elocuencia y hacer de ésta una condición indispensable en la transmisión del conocimiento ${ }^{25}$, había de mostrarse muy escéptico ante la validación de la historia como disciplina sobre la base de la elocuencia. Puesto que no requería de la ciencia escolástica que se transmitía en las universidades para su cultivo, las aptitudes intelectuales que éste exigía no habían de ser muy elevadas.

Y sin embargo, había de justificar don Alonso sus afanes historiográficos. De ahí que se vea precisado a declarar la pertinencia del conocimiento histórico, en la medida en que el deseo de saber historia es algo razonable. Al glosar, al desarrollar la naturaleza de sus contenidos, ofrece un testimonio precioso de cuáles eran sus intereses historiográficos: qué ha sucedido desde el pasado más remoto hasta el más inmediato, tanto en la propia tierra como en la ajena y, más específicamente, la serie de los gobernantes que han ejercido el poder allí donde uno habita ${ }^{26}$. Dos coordenadas definen el ámbito de su interés, espacial y cronológico. Para el marco geográfico utiliza los términos regio y terra. El primero resultaba semánticamente neutro, dado que con él se designaba cualquier territorio, mientras que el segundo presentaba una precisa significación política: equivale a patria y se erige en uno de los

\footnotetext{
23 "Sed hoc vnu(m) inter caetera, quod nec ingenii altitudinem poscit, nec etiam capacitatem, licet mediocrem aut paruam transcendit, contemnendum non est" (Anacephaleosis, Praefatio, p. 611).

${ }^{24}$ Y en efecto, el prólogo de Lorenzo Valla a su historia del rey Fernando de Aragón, contiene una vindicación de la historia que parece confutada por las consideraciones de Alonso de Cartagena [Laurentius VALLA, De rebus a Ferdinando Aragoniae gestis, Prooemium (R. BELL, ed.), Rerum Hispanicarum Scriptores t. I, p. 1005]. Para la concepción humanística de la historia, véase Rudiger LANDFESTER, Historia Magistra Vitae. Untersuchungen zur humanistischen Geschichtstheorie des 14. bis 16. Jahrhunderts, Ginebra, 1972, pp. 65-70, 80-94. Es probable que don Alonso tuviera conocimiento, dada la vinculación de su familia con los Trastámarạ de Aragón, de la obra del gran humanista italiano; llama poderosamente la atención la presencia en ambos prólogos de temas comunes.

${ }^{25}$ Que se manifestó inequívocamente en el libelo polémico contra Leonardo Bruni. Sobre esta dimensión de la célebre polémica, véase L. FERNÁNDEZ GALLARDO, En torno a los «studia humanitatis» en la Castilla del Cuatrocientos. Alonso de Cartagena y los autores antiguos, "En la España Medieval", 22 (1999), pp. 218-225.

26 "Historiarum quippe notitia, audiendi quid in sua, quidve in aliena regione antiquis in saeculis \& prope nostra te $(\mathrm{m})$ pora actu(m) sit, \& qui principes has terras quas incolimus, per diuersa saecula gubernarunt, rationi co(n)gruum desideriu(m) est" (Anacephaleosis, Praefatio, $\mathrm{p}$. 611).
} 
principios que aglutinan el sentimiento comunitario ${ }^{27}$. Esto se debe a que con dicho término apuntaba al ámbito propio, cuya serie de príncipes interesa conocer. El interés histórico de Alonso de Cartagena es primordialmente político: antes que a una historia nacional aspira a una historia del poder, más bien de la serie quienes lo ejercieron. Al designar a éstos como principes, estaba sugiriendo una serie bien definida, la de quienes ejercieron el principatus, esto es, un poder soberano, exento de cualquier otra instancia política. Ahora bien, el principatus coincide en España con la institución monárquica, de manera que los principes aludidos no son sino los reyes que han ejercido el poder soberano en España -habría que precisar, no necesariamente "sobre" España. El interés del obispo de Burgos se centra no tanto en la individualidad de cada uno esos principes sino en su sucesión temporal ("per diuersa saecula"); en definitiva, en la continuidad dinástica.

Como si sintiera que tal justificación resultaba débil o insuficiente, don Alonso añade otras consideraciones para avalar la pertinencia del saber histórico. Y en este punto, introduce un argumento que ciertamente sorprende. En efecto, la limitada visión del pasado que revela ese interés centrado en la sucesión dinástica de la realeza hispana se abre hasta abarcar todo asunto humano, para lo que aduce una cita que no podía ser más oportuna, el famoso dictum terenciano: "Homo sum, nihil humanum alienum puto" ${ }^{28}$. Diríase que el obispo de Burgos tuvo una honda intuición acerca de la naturaleza del conocimiento histórico, de la que no fue plenamente consciente, en la medida en que atisbaba su último y radical fondo humano y, por tanto las posibilidades para una renovación de la práctica historial en una línea análoga a la que preconizaban los humanistas italianos, quienes al incluir la historia en la serie de disciplinas que componen los studia humanitatis ${ }^{29}$ estaban destacando su esencial contribución al desarrollo de la humanitas. Tal vez esa intuición de lo que debería ser el auténtico y cabal objeto de la historia le viniera sugerida por la lectura de las reflexiones que sobre la historia incluye el De oratore de Cicerón, que pasaron a ser la referencia canónica de la historiografía humanística $^{30}$. Mas Cartagena orientó la virtualidad humanística del saber histórico hacia la consabida y trillada dirección ejemplar, como pone inequívocamente de manifiesto el gran proyecto historiográfico que su muerte

\footnotetext{
${ }^{27}$ Para el significado de patria, véase A. de CARTAGENA, Oracional, Murcia, 1487, sig. c $4^{\circ}$. Para la noción de patria en Cartagena, véase L. FERNÁNDEZ GALLARDO, Alonso de Cartagena, pp. 405-417.

${ }^{28}$ Anacephaleosis, Praefatio, p. 611. Es lo más probable que la cita esté tomada del $D e$ officiis ciceroniano (Robert Brian TATE, La Anacephaleosis de Alfonso García de Santa María, in Ensayos sobre la historiografía peninsular del siglo XV, Madrid, 1970, p. 67).

${ }^{29}$ Paul Oskar KRISTELLER, Renaissance Thought and its Sources, Nueva York, 1979, p. 22 August BUCK, Die «studia humanitatis» im italienischen Humanismus, in Studien zu Humanismus und Renaissance, Wiesbaden, 1991, pp. 103-119.

30 "Historia vero testis temporum, lux veritatis, vitae memoriae, magistra vitae, nuntia vetustatis, qua voce alia nisi oratoris immortalitati comendatur?" (CICERÓN, De oratore, II, 36). Mas, por otra parte, al encomendarse su cultivo al orador, se estaba destacando la elocuencia como fundamento epistémico de este saber y, por tanto, su desvalorización como disciplina carente de scientia.
} 
frustró: la adaptación a la vez cristiana e hispana de los Dicta et facta memorabilia de Valerio Máximo ${ }^{31}$.

Otra faceta de interés descubre la justificación no de la historia en sí, sino del texto histórico. Tras la concesión a sus irrenunciables convicciones escolásticas, la afirmación del carácter no necesario, luego prescindible, de los conocimientos históricos, don Alonso destca dos cualidades que éstos poseen: son útiles y deleitables a la vez ${ }^{32}$. Ambas remiten inequívocamente a la teoría poética de Horacio, en una formulación de la función de la poesía que ha gravitado sobre la tradición literaria occidental, marcando las coordenadas de la reflexión sobre la naturaleza del hecho literario ${ }^{33}$. Ahora bien, sin descartar que el prelado burgalés evocara los versos del vate romano $^{34}$, es lo más probable que la atribución a la historia de las dos cualidades propias de la poesía le viniera sugerida por las reflexiones al respecto que Valla incluyó en el prólogo de su ya citada historia de Fernando de Antequera ${ }^{35}$. Esa atracción de la historia a la órbita de la poesía venía a confirmar la condescendiente estimación de su naturaleza epistémica.

\section{El género: entre la genealogía y la historia}

Pues bien, la convicción de Alonso de Cartagena en la idoneidad y pertinencia del conocimiento histórico se plasma en una obra que se aparta de la práctica historiográfica habitual, en la medida en que integra las características formales de la genealogía -en su consabida representación arbórea- y de la historia. La elección de este inusual molde genérico se halla determinada tanto por la idea de la historia que tiene su autor, como por la finalidad con que éste concibió su obra. Al situar la sucesión de los principes en el primer plano de sus preocupaciones históricas, era obvio que la genealogía ofrecía el marco formal idóneo. Mas su representación gráfica y la reducción al mínimo imprescindible de la narración histórica no responden a otro designio que el de facilitar su memorización ("hoc continue in memoria habere"), puesto que no otra finalidad motivan los desvelos historiales del obispo de Burgos: ofrecer la información esencial que resultara relevante para aquellas ocasiones en que había que tratar de asuntos históricos (conversación, debate...)

\footnotetext{
${ }^{31}$ Que sería llevado a cabo por su fiel discípulo Diego Rodríguez de Almela.

32 "At licet hoc co(n)tinue in memoria habere necessarium non erat, vtile tamen pariter ac delectabile censeo" (Anacephaleosis, Praefatio, p. 611).

33 "Aut prodesse uolunt aut delectare poetae

aut simul et iucunda et idonea dicere uitae. [...]

Omne tulit punctum qui miscuit utile dulci ,

lectorem delectando pariterque monendo ..”
(HORACIO, Ars poetica, vv. 334-335, 343-344)

${ }^{34}$ Precisamente por esos años tiene lugar en España el desarrollo del denominado "renacimiento horaciano", que inicia el Marqués de Santillana (Marcelino MENÉNDEZ PELAYO, Horacio en España, II, Obras completas, Madrid, 1951, t. XLIX, p. 291).

35 "Sed hoc, vt dixi, donamus, satis habemus demonstrare, cum idem sit propositi historico quod poetae vt prosit, etiam delectet, nimirum tanto robustiorem esse historiam quanto est verior" (L. VALLA, De rebus, Prooemium, p. 1006). Líneas más atrás había aducido el Ars poetica de Horacio, por lo que es obvia en este pasaje la cita de los versos mencionados.
} 
La genealogía permitía la integración de imagen y narración en un mismo espacio textual. En efecto, este género historiográfico se caracteriza por su doble naturaleza verbal e icónica ${ }^{36}$, por lo que se revelaba como el cauce idóneo para que se manifestara una concepción eminentemente política de la historia que centra su interés en la sucesión de principes, esto es, en la serie dinástica $^{37}$, a la vez que permitía reducir a lo esencial la información histórica pertinente. Por otra parte, la Genealogía de Alonso de Cartagena se enmarca en el contexto del desarrollo de la materia genealógica que se observa en la Península Ibérica, tanto entre la nobleza como entre las casas reales hispanas ${ }^{38}$. De hecho, se ha aducido un testimonio de este florecer, el denominado Rollo Genealógico de Poblet (principios del siglo XV), que presenta un aparato icónico análogo al de la Genealogía $a^{39}$.

Ahora bien, la obra de Cartagena no es una genealogía sin más. Su intención declarada era componer un árbol genealógico que incluyera el componente narrativo propio de la historia ${ }^{40}$. Así, pues, el núcleo básico de la obra era el dispositivo gráfico de representación de la genealogía de los reyes de España. El verbo "conscribere" sugiere la alineación en serie de los distintos monarcas hispanos, formando más bien una cadena de sucesión, de manera análoga al "árbol" que figura como apéndice de la versión latina conservada en al Archivo Histórico Nacional ${ }^{41}$, de ahí que en las versiones castellanas se traduzca este término por "tabla". La expresión "conscribere feceram" apunta, antes que a la realización personal, a un encargo. El obispo de Burgos elaboraría, de este modo, una relación en forma de minuta o borrador que un amanuense e iluminador dispondría en la forma gráfica adecuada.

La adición de los "gesta" correspondientes a los distintos monarcas constituye la inclusión del componente narrativo propio de la historia, término éste que posee una precisa significación en el sistema de los géneros

\footnotetext{
${ }^{36}$ Conforme a la definición de uno de sus mejores conocedores: “ $\ldots$ oeuvre independante, écrite ou dessinée, pour faire connaître la filiation d' une famille ou " "un individu" (Léopold GENICOT, Les génealogies, in Typologie des sources du Moyen Age Occidental, fasc. 15, Turnhout, 1975 , p. 11.

${ }^{37} \mathrm{Hay}$ que tener presente que la genealogía era el "document plus naturel pour une monarchie héréditaire" (Bernard GUENEE Les généalogies entre l histoire et la politique: la fierté d'être capétien en France au Moyen Âge, in Politique et histoire, París, 1978, p. 452). La genealogía se inscribe a su vez dentro de las series iconográficas de la realeza [David NOGALES RINCÓN, Las series iconográficas de la realeza Castellano-leonesa (siglos XII-XV), "En la España Medieval", (2006) Anejo I, pp. 81-111]. Penetrante análisis del significado político de la serie genealógicá en R. FOLGER, Generaciones, pp. 159-162. Una perspectiva historiográfica general acerca del género genealógico en Gabrielle M. SPIEGEL Genealogy: Form and Function in Medieval Historical Narrative, "History and Theory", XXII/1 (1983), pp. 43-53.

${ }^{38}$ Eduardo PARDO DE GUEVARA, Presencia de la materia genealógica en la literatura histórica medieval, in Pensamiento medieval hispano. Homenaje a Horacio Santiago-Otero (J.M ${ }^{\mathrm{a}}$ SOTO RÁBANOS, coord.), Madrid, 1998, I, pp. 399-401.

${ }^{39}$ Contiene árboles genealógicos de los Condes de Barcelona y de los Reyes de Aragón (Elías TORMO, Las viejas series icónicas de los reyes de España, Madrid, 1916, pp. 57-59; E. RUIZ GARCÍA, Avatares, p. 309).

40 "Hac itaq(ue) intentione motus conscribere feceram arborem quandam genealogiae Regum Hispaniae, eorum gesta aliquantulum miscens..." (Anacephaleosis, Praefatio, p. 611).

${ }^{41}$ Va precedido de la siguiente indicación: "S(e)quitur arbor plana ad facilius inuenienda nomina Regu(m) Ispanie" (AHN, cód. 983 B, f. 46 r. b). El árbol, en ff. 46 v.-50 v.
} 
historiográficos del Medievo. La terminología utilizada por el prelado burgalés es rigurosa al respecto; al identificar historia y gesta revela su entronque con la doctrina histórica de San Isidoro ${ }^{42}$.

Alonso de Cartagena manifiesta una clara conciencia de la naturaleza formal de su obra. Distingue netamente entre la parte icónica, que designa con el termino arbor, el componente estrictamente genealógico, y la verbal, que denomina historia. La primera, por su brevedad, facilita su memorización o la rápida localización de los datos relativos a la serie dinástica, en tanto que la segunda ofrece aquella información relevante que se añade a los lazos de parentesco definidos por la genealogía.

Sin embargo, aunque el obispo de Burgos concibió su obra como un producto híbrido de naturaleza icónica y verbal, muy pronto adquirió autonomía el componente verbal, liberándose de la relación de complementariedad que mantenía con el aparato icónico. Así, un temprano testimonio manuscrito de la versión latina de la Genealogía, cuyo relato se continuó hasta el reinado de los reyes Católicos, carece de imagen alguna o de espacio en blanco reservado para su ejecución ${ }^{43}$, prueba inequívoca de que la parte verbal era considerada como texto autónomo que no necesitaba de la información que podía aportar el árbol genealógico. Los testimonios impresos tampoco incluyen el aparato icónico, por lo que la versión que en definitiva se consagró en la medida en que tuvo una mayor difusión, aunque reducida a los círculos eruditos, se apartaba de la forma genuina de la obra tal y como la concibió su autor. Esta traición al proyecto original de la Genealogía se debía precisamente al prestigio creciente de la figura egregia de Alonso de Cartagena, que determinó que se rescatara de la suerte incierta de la transmisión manuscrita merced a la imprenta aquello que se consideraba genuina expresión de su saber y erudición, la historia.

\section{EL ELEMENTO ICÓNICO}

\section{Justificación. De teoría mnemotécnica}

A la disposición gráfica de la genealogía en forma de árbol, Alonso de Cartagena decide añadir las representaciones de los propios monarcas. Concibe éstas como un componente netamente diferenciado del "árbol" ${ }^{4}$. La justificación de esta adición de elementos icónicos ${ }^{45}$ remite a la concepción de la memoria corriente entonces, que derivaba de la teoría retórica, de la que su más destacado representante es la pseudo-ciceroniana Rhetorica ad

\footnotetext{
${ }^{42}$ Para estas cuestiones véase L. Fernández Gallardo, Alonso de Cartagena, pp. 282-283.

${ }^{43} \mathrm{BNM}$ ms. 13260. No es de extrañar que una mano distinta de la del cuerpo del texto, ya del siglo XVI, le atribuyera el siguiente título: "De regibus Hispanie" (f. 13 r.), indicio de que quedaba olvidado su carácter de genealogía.

44“... Reges ipsos congruo arboris loco depingi feci..." (Anacephaleosis, Praefatio, p. 612).

45"At quia imagines rerum fortius memoriam coadiuuant, quam nuda scriptura..." (Anacephaleosis, Praefatio, p. 612).
} 
Herennium, que precisamente don Alonso tradujo para el príncipe luso don Duarte. El término imagines constituye un tecnicismo retórico, que designa uno de los recursos de la memoria $\operatorname{artificios}^{46}$. La imagen a que se refiere el obispo de Burgos es aquella que tiene su similitud con la cosa que ha de ser recordada.

Las técnicas mnemotécnicas ${ }^{47}$ ocupaban un relevante papel en la pedagogía de la época, en la que a pesar de la omnipresencia de la escritura, la oralidad todavía desempeñaba un relevante papel. Un testimonio doblemente significativo, por provenir de un eximio jurista, ofrece el tratado pedagógico que en 1453 compuso el canonista salmantino Juan Alfonso de Benavente, que dedica un amplio capítulo a la memoria, inexcusable etapa del proceso de estudio $^{48}$. Partiendo de la doctrina de la Rhetorica ad Herennium, el canonista ilustra con ejemplos de su objeto de estudio las distintas estrategias memorísticas. Algunas observaciones diríase que ofrecen la clave del propósito que anima el programa iconográfico de la Genealogía, como la recomendación de que el estudiante construya imágenes vivas y realizando algo ${ }^{49}$, que vendría a dar razón de la concentración del interés de Cartagena en el gesto y la acción relevante de los personajes representados. Las consideraciones del canonista salmantino ponen de manifiesto de qué manera estaba arraigada en la cultura letrada el cultivo de la memoria conforme a técnicas y estrategias que hallaban su referente teórico en la doctrina retórica, tal y como fuera formulada en la Rhetorica ad Herennium. El recurso a la imagen en la Genealogía se justificaba, por tanto, desde los presupuestos de la cultura letrada y desempeñaba una precisa función en la intención del autor: facilitar la memorización de aquella información que se consideraba esencial ${ }^{50}$.

\section{Plan general de la serie icónica}

Las indicaciones que ofrece Alonso de Cartagena en el prólogo de su Genealogía acerca de su proyecto iconográfico son sumamente esquemáticas. Se limitan a precisar el objeto de la representación, su ubicación y la jerarquía establecida. Las imágenes corresponden a los reyes cuya serie componen la magna genealogía y a aquellos personajes que se distinguieron por su strenuitas, cualidad que apunta a la valentía o fortaleza de ánimo, la virtud propia del estamento caballeresco. Debido a la diferencia de rango entre

\footnotetext{
46" Constat igitur artificiosa memoria locis et imaginibus, [...] Imagines sunt formae quaedam et notae et simulacra eius rei quam meminisse volumus..." (Rhetorica ad Herennium, III, 29). Para su desarrollo: III, 33-37.

${ }^{47}$ Veéase Mary CARRUTHERS, The Book of Memory. A Study of Memory in Medieval Culture, Cambridge, 1990, pp. 153-194.

${ }^{48}$ Juan Alfonso de BENAVENTE, Ars et doctrina studendi et docendi (B. AlONSO RoDRÍGUEZ, ed.), "Salmanticensis", 19 (1972), pp. 84-91. p. 86).

49 “Et ponat ymagines semper uiuas et aliquid agentes ut melius recordentur" (Ibídem, § 70,

${ }^{50}$ Reconoce una finalidad mnemotécnica y a la vez conmemorativa a los retratos regios $\mathrm{R}$. FolgER, , A Genealogy of Castilian Historiography: From nomina regum to semblanzas, "La corónica”, 32/3 (2004), pp. 51, 63.
} 
ambas categorías de personajes y al agudo sentido de las jerarquías sociales que tenía el obispo de Burgos, no es de extrañar que las mínimas instrucciones para la elaboración del aparato icónico apunten a la expresión gráfica de dichas diferencias. Para ello se arbitran dos procedimientos: la ubicación y la forma de la representación. Los reyes han de situarse en el lugar correspondiente del árbol, mientras que los personajes destacados han de figurar en el margen. A su vez, los reyes serán representados de cuerpo entero, mientras que de los personajes notables solo se ofrecerá su busto. La norma incluye asimismo la excepción, que afecta a dos destacados personajes, el Cid y el conde Fernán González, representados ambos a caballo, debido a su eximio valor $^{51}$. Esta asimilación de los dos héroes castellanos a la realeza, llevada a cabo en el plano iconográfico, constituye un claro signo de exaltación castellanista, al parangonarse con los reyes dos hitos de la historia de Castilla.

La jerarquización del espacio material del texto escrito sirve para representar el orden social: de la misma manera que los márgenes constituyen el espacio de la glosa, del texto subalterno, allí serán incluidas las personalidades no regias. Alonso de Cartagena proyecta de este modo su prolongada experiencia con las convenciones de la escritura académica para configurar su programa iconográfico.

Si bien tales indicaciones fueron respetadas en algunos de los primeros testimonios de la obra, como la versión castellana más antigua ${ }^{52}$, la idea original del obispo de Burgos fue pronto abandonada. Ya en los manuscritos latinos más tempranos se observa la contravención de las instrucciones sobre la representación establecidas en el prólogo. El manuscrito A hace saltar a los personajes no reales la linde de los márgenes, presentándolos en ocasiones en la misma escena junto con el rey; muy significativamente, junto al primer monarca, Atanarico, aparece el obispo Gudila, de cuerpo entero y sedente, sin marca icónica alguna que exprese jerarquía. Ambas figuras están yuxtapuestas; no parecen integrarse en un mismo espacio, una misma escena ${ }^{53}$. El continuador de las ilustraciones, aunque más torpe en el trazo del dibujo, gustaba de reunir al rey con otras personalidades en animadas escenas. Especialmente significativo es el caso del iluminador del manuscrito $\mathrm{P}$, acaso Jorge Inglés ${ }^{54}$ a quien el gusto por la composición dramática le llevó al extremo de infringir los principios iconográficos establecidos por el obispo de Burgos, atribuyendo espada, atributo de monarca belicoso, a Favila, del que solo se recuerda su muerte en accidente cinegético. Más flagrante aún es el caso de la representación de Gesaleico que hizo el iluminador del manuscrito

\footnotetext{
51 “Depinguntur autem descendentes per lineam Laini Calui in margine omnes per capita exempto Cido, qui „propter strenuitate operum depingitur integre, \& supra equum, sicuti Fernandus Comes..." (Anacephaleosis, p. 646).

${ }^{52} \mathrm{El}$ manuscrito escurialense $\mathrm{E}^{1}$, que utiliza estampaciones hechas mediante matrices metálicas, técnica de la que ofrece el primer testimonio castellano (E. RUIZ GARCÍA, Avatares, pp. 314-315).

${ }^{53}$ AHN, cód. 983 b, f. 8 v.

${ }^{54}$ Sobre estas ilustraciones, véase E. TORMO, ob. cit., pp. 219-239; Isabel MATEO GóMEZ, Sobre el autor de los dibujos de la Genealogía de los Reyes de don Alonso de Cartagena, Burgos, 2005 .
} 
N4: a caballo, para realzar su fuga de la batalla ${ }^{55}$, cuando el retrato ecuestre era signo de excelencia bélica.

Las normas del programa iconográfico elaborado por Cartagena se revelaban, por tanto, demasiado restrictivas para la necesidad expresiva de los iluminadores, que debieron de sentir un conflicto entre el principio jerárquico general enunciado en el prólogo y las indicaciones específicas sobre la imagen de cada monarca que aparecen ya en el cuerpo del texto y que constituían una invitación a cierta dramatización para su mayor eficacia representativa. No solo ese desajuste, sino la propia índole creativa de los ilustradores desviaba el centro de interés de la imagen desde la subordinación al mensaje verbal al desarrollo propiamente formal, como revela el gusto del autor de las ilustraciones del manuscrito $\mathrm{P}$ por la lujosa ornamentación del vestuario de los personajes $^{56}$.

A su vez, los ilustradores añadieron por su cuenta elementos que desde la perspectiva de la economía del sistema elaborado por don Alonso resultaban superfluos. Así, común a todos ellos es la representación de los monarcas con corona, atributo redundante. Aún más lo es el cetro que el autor de las ilustraciones del manuscrito N4 colocó en la diestra de los reyes.

\section{Imagen y glosa}

Dado que las imágenes no tienen un simple valor ornamental, sino que se subordinan a una estrategia mnemotécnica, cumpliendo una función claramente definida, el obispo de Burgos no podía dejar al libre arbitrio del iluminador la representación de los reyes que componen la serie genealógica. De ahí que ofrezca las indicaciones icónicas precisas con relación a la información que pretendía destacar en cada uno de los monarcas ${ }^{57}$. La recurrencia de determinadas instrucciones pone de relieve un sistema iconográfico, que no es sino la manifestación de la concepción de la realeza que está en la base de los escritos políticos de Alonso de Cartagena y que constituye el punto de referencia de su estimación de la realeza hispana.

Dado que la imagen tiene por cometido facilitar la memorización de los contenidos narrados, el docto prelado burgalés no quiere asumir el riesgo de una interpretación inadecuada de ella o ver reducida su eficacia mnemotécnica, por lo que declara explícitamente su significado. Más que de mera

\footnotetext{
${ }^{55} \mathrm{BNM}$, Vit. 19-2, f. $10 \mathrm{v}$.

${ }^{56}$ Interés análogo al mostrado por el dibujante Maso Finiguerra, ilustrador de una crónica florentina que "utilizaba las efemérides de la historia universal como excusa perfecta para describir la magnificencia del vestuario" [Aby WARBURG, Crónica pictórica de un orfebre florentino (1899), in El renacimiento del paganismo. Aportaciones a la historia cultural del Renacimiento europeo, Madrid, 2005, pp. 133b].

${ }^{57}$ El resultado semeja el caso, donosamente aducido por don Quijote, de aquel Orbaneja, "pintor de Ubeda, al cual preguntándole qué pintaba, respondió: «Lo que saliere». Tal vez pintaba un gallo, de tal suerte y tan mal parecido, que era menester que con letras góticas escribiese junto a él: "Este es gallo»" (Quijote, II, 3). ¿Ácaso don Alonso temía habérselas con Orbanejas como ilustradores de su obra?
} 
instrucción para el iluminador ${ }^{58}$ se trataría de información para el lector. En efecto, el verbo que introduce las instrucciones icónicas es indefectiblemente "depingitur" (o en plural "depinguntur"), un presente de indicativo, en lugar del subjuntivo con valor yusivo depingetur que cabría esperar si se tratara solo de una indicación para el iluminador. A su vez, tras las precisas instrucciones relativas a la disposición de la ilustración, se incluye una explicación introducida siempre por la conjunción causal "quia", que, al justificar ésta, constituye el punto de unión de la narración y de la imagen, del mensaje verbal y del icónico. La imagen requiere, por consiguiente, una intelección retórica: referida no tanto a un objeto, sino a un texto ${ }^{59}$. De este modo, se comprueba cómo Alonso de Cartagena diseñó con extremo detalle el componente iconográfico de la Genealogía, prescribiendo cuidadosamente los elementos esenciales de la representación, para lograr la plena eficacia funcional de la imagen, que no se abandona en modo alguno a la capacidad creativa e inventiva del iluminador de turno.

\section{EL SISTEMA ICONOGRÁFICO}

\section{Las variables}

Puesto que el objeto de la representación son los personajes que conforman la serie genealógica de la realeza castellana, la imagen está ideada esencialmente para facilitar el recuerdo de los monarcas. Para ello, Cartagena elabora un sencillo sistema iconográfico en el que se distinguen dos grandes categorías de imágenes: las referidas al atuendo del rey -entre las que se incluyen aquellas relativas a elementos que porta el monarca (espadas, estandartes...) y las que indican un gesto ${ }^{60}$ o acción destacada de éste. Obviamente no se presentan necesariamente disociadas ambas categorías, pues el hecho de portar un elemento con significado simbólico conllevaba la

\footnotetext{
${ }^{58}$ Aunque el carácter de indicación para el iluminador se pone claramente de manifiesto en la ilustración de Alarico. De la ciudad representada no se dice directamente que es Roma, sino una ciudad cualquiera: "Depingitur autem Alaricus [...] enseque nudo in manu, eleuata contra cuiusdam imaginem vrbis, propter emersionem quem fecit in vrbem Romanam..." (Anacephaleosis, p. 622). Hay que entender el indefinido "culusdam" en el sentido de que el iluminador había de representar simplemente una ciudad, sin el menor cuidado por ser fiel a la concreta fisonomía urbana, pues el texto permitía identificarla con Roma. La imagen no es un icono en estricto sentido semiológico, sino símbolo. Tal vez este hecho, explique el uso de un mismo taco xilográfiço para ilustrar varias ciudades en algunas obras impresas, antes que la mera economía, como se interpreta en Elizabeth EISENSTEIN, La revolución de la imprenta en la Edad Moderna europea, Madrid, 1983, p. 67.

${ }^{59}$ Sobre la naturaleza "textual" que poseía la imagen en la cultura mnemotécnica y visual del Medievo, véase M. CARRUTHERS, ob. cit., pp. 221-222.

${ }^{60}$ Para la importancia del atuendo, los atributos sociales y los gestos en el Medievo, sigue siendo válida la siguiente observación del viejo estudio de H. Keller (1939): "Für die früh- und hochmittelalterliche Menschendarstellung... erfolgt die Identifizierung einer Persönlichkeit nicht durch das Gesicht. Die Kleidung und die Geste, die Art des Thronens und die Zusammensetzung des Gefolges geben weit besser Aufschluß über die Persönlichkeit eines Herrschers als sein Antlitz". (ápud Bruno REUDENBACH, Individumm ohne Bildnis? Zum Problem künstlerischer Ausdrucksformen von Individualität im Mittelalter in Individuum und Individualität im Mittelalter, (J.A. AERTSEN; A. SPEER, eds.), Berlín-Nueva York, 1996, p. 810).
} 
realización de un gesto, como por ejemplo empuñar una espada, a la vez que el rey con su atuendo correspondiente podía aparecer llevando a cabo una acción determinada. Con los términos "gesto" y "acción" se pretende diferenciar dos tipos de actuación representados. Con el primero se designa el gesto que se halla codificado, inserto en el sistema iconográfico elaborado por Cartagena, y tiene un signifcado simbólico, no "literal", esto es, no remite a una acción efectivamente realizada por el personaje representado. El segundo designa un hecho que realmente llevó a cabo el monarca que figura en la imagen. A este respecto resulta especialmente útil la formulación de las categorías de "síntoma natural" (gesto espontáneo que acompaña a la manifestación de un estado de ánimo determinado) y "símbolo convencional" (gesto ritualizado), como extremos de un espectro en la cinesis humana ${ }^{61}$. El "gesto" se correspondería así con el "símbolo convencional" y la "acción" con el "síntoma natural". A este esquema básico cabría añadir alguna indicación ocasional, como la relativa a la edad, si el monarca en cuestión murió en la infancia, adolescencia o senectud ${ }^{62}$.

Tan somera caracterización sirve como indicio de algún hecho destacado o más directamente como esquemática etopeya -mas no individual, sino institucional, integrada en el marco de las virtudes regias. En cualquier caso, las imágenes ofrecen una valoración de los monarcas, una estimación basada en la versión canónica de la historia hispana y fundamentada en la concepción del poder real de quien fuera uno de los principales ideólogos del reinado de Juan II.

\section{El atuendo bélico o la expresión de la fortitudo}

Dentro de la primera categoría cabe distinguir dos grandes grupos: el atuendo bélico y el pacífico. En el primero, a su vez, se incluyen tres modalidades de representación: armado, empuñando una espada desnuda y a caballo. Diríase que componen una gradación de la excelencia bélica, de manera que la plenitud de las virtudes bélicas se representa mediante imagen ecuestre. La forma más habitual es la primera. La expresión más habitual es "armatus"; se utilizan también formas más ampulosas: "sub cultu armorum", "sub armato culto".

Los otros dos grupos suponen un mayor mérito en las cualidades guerreras. En primer lugar la espada, uno de los principales objetos que simbolizan el poder real ${ }^{63}$, que se presenta integrada en el gesto de empunarla. Alonso de Cartagena introduce un detalle sumamente significativo, el monarca

\footnotetext{
${ }^{61}$ Ernst H. GOMBRICH, Gesto ritualizado y expresión en el arte, in La imagen y el ojo. Nuevos estudios sobre la psicología de la representación pictórica, Madrid, 1987, p. 62.

${ }^{62}$ Aunque en el caso de Recaredo II se recurre a la vestimenta para representar esta circunstanciä: "Depingitur autem puer, \& in veste puerili..." (Anacephaleosis, p. 630).

${ }^{63}$ Precisa exposición de su valor de símbolo de la realeza en José Manuel NIETO SORIA, Ceremonias de la realeza. Propaganda y legitimación en la Castilla Trastámara, Madrid, 1993, pp. 188-190.
} 
portador la empuña desnuda ${ }^{64}$. Con ello viene a expresar de modo inequívoco su condición de atributo esencialmente bélico, antes que la de símbolo de la justicia $^{65}$, pues pretende destacar que no se trata de un arma meramente ceremonial, sino que se halla dispuesta para su cometido primario, la lucha. Si se tiene en cuenta que en España la espada tuvo una mayor relevancia como símbolo de la realeza que la corona ${ }^{66}$, se colige que el obispo de Burgos quería expresar mediante la imagen que la excelencia regia se alcanzaba mediante el cultivo de las armas: la espada alzada en ademán acometedor simbolizaría la plenitud de la virtud esencial de la realeza, la fortaleza de ánimo. Ahora bien, no se trata de simple vocación por las armas, sino de su ejercicio en la misión que providencialmente tiene asignada la realeza castellana: la lucha contra el infiel. De ahí que Enrique II, rey del que se dice que fue "bellicosus", sea representado con indumentaria pacífica al no haber emprendido campañas contra los moros ${ }^{67}$. En la imagen de Sancho IV adquiere carácter triunfal, ya que este monarca no aparece representado con atavío bélico, pues su actividad guerrera fue limitada, pero, dado que conquistó Tarifa, tan señalado hecho de armas exigía su perpetuación en la memoria, por lo que se le añade la espada desnuda $^{68}$. A su vez, este motivo iconográfico admitía su inversión: la espada arrebatada de la mano, que aparece en la representación de Gesaleico, deviene entonces signo opuesto: expresa no la excelencia guerrera, sino la degradación de las virtudes bélicas que este rey mostró con su huida del campo de batalla ${ }^{69}$.

Mas la espada no se limita a realzar las virtudes bélicas de los reyes que la empuñan. En la imagen de Recaredo, don Alonso declara explícitamente su significado, que añade así uno de los valores simbólicos habituales: en tanto que defensora de la fe, se trataría de la espada del propugnator Ecclesiae. ${ }^{70}$ Ya en el Defensorium unitatis christianae, el prelado burgalés había planteado el deber del príncipe de acudir con las armas en defensa de

\footnotetext{
${ }^{64}$ Precisamente, en el ceremonial de coronación preparado para Alfonso XI, se indica, a propóșito de la espada en tanto que atributo regio, lo siguiente: "La espada del Rey deue seer nuda sin uayna..." (ápụd Claudio SÁNCHEZ-ALBORNOZ, Un ceremonial inédito de coronación de los reyes de Castilla, in Viejos y nuevos estudios sobre las instituciones medievales españolas, Madrid, 1983, t. II, p. 1246).

${ }^{65}$ Que es, por otra parte, el significado más corriente (Jean FLORI, L'Idéologie du glaive. Préhistoire de la chevalerie, Ginebra, 1983, p. 169). No obstante, el obispo de Burgos contempla también este valor simbólịco en la representación de Enrique III: “Depingitur [...] ensem habens in manu propter [...] iustitiae zelum quem habuit..." (Anacephaleosis, p. 660).

${ }^{66}$ Véase al respecto Bonifacio PALACIOS MARTín, Los símbolos de la soberanía en la Edad Media española. El simbolismo de la espada, in VII Centenario del Infante D. Fernando de la Cerda, Madrid, 1976, pp. 273-296.

67 "Depingitur Enricus in veste pacifica, quia licet bellicosus fuit, no(n) tamen cum Arabibus pugnauit" (Anacephaleosis, p. 658).

68 "Depingitur in veste longa, \& ense nudo in manu, quia licet multa bella no(n) gessit, obtinuit tamen Tarifam" (Anacephaleosis, p. 655).

69 "Depingitur Giselaricus in veste pacifica, ense extra manum erepto, quia armis depositis figitiuus euasit" (Anacephaleosis, p. 625).

70 "Habet etia(m) ensem nudum in alia manu... Sic enim decet Principes catholicos, fidem nedum monitis, sed etiam ense tueri" (Anacehaleosis, pp. 628-629). Para dicho valor simbólico, véase J. FLORI, L'Idéologie du glaive, p. 169.
} 
la fe; parra la expresión de dicho principio recurrió al simbolismo de esta arma, sobre el que proyectó la doctrina de las dos espadas ${ }^{71}$.

La imagen ecuestre tiene una presencia mucho más restringida que la anterior. En la glosa correspondiente suele aparecer asociado al término de lo que hemos denominado primera modalidad del atuendo bélico ("armatus in equo"), con lo que viene a sugerirse que la representación ecuestre constituye algo así como un valor añadido a las virtudes belígeras: muy significativamente en la glosa de la representación ecuestre de Alfonso XI se utiliza el adjetivo "bellicosus" en grado superlativo ${ }^{72}$. Don Alonso la reserva a aquellos monarcas y personajes que marcaron hitos en el devenir histórico de Castilla adquiriendo el carácter de atributo de rango máximo en la expresión de las virtudes regias, pero limitado a la exaltación castellanista. De ahí que no sea casual que los primeros personajes a quienes se aplica la representación ecuestre sean precisamente dos de las referencias míticas de la identidad histórica castellana, Fernán González y el $\mathrm{Cid}^{73}$. Ninguno de los reyes anteriores, ni siquiera el fundador de la estirpe goda, a pesar de que sobre tal prosapia se hacía pivotar el prestigio de la realeza castellana, gozó de la imagen que expresaba la plenitud de las virtudes bélicas. Los reyes que aparecen así seleccionados son Fernando I, Alfonso VIII, Fernando III, Alfonso XI e, inevitable concesión a la adulación cortesana, los dos contemporáneos, Juan II y Enrique IV, cuyas iniciativas bélicas contra el reino de Granada se parangonan con los grandes hitos de la Reconquista.

La representación de Juan I puede considerarse como inversión de la imagen ecuestre. Mas en este caso el caballo no constituye un símbolo de excelencia guerrera, sino elemento real de una escena de carácter narrativo: la caída del caballo que le produjo la mortal herida al monarca ${ }^{74}$. En efecto, las instrucciones iconográficas van precedidas precisamente de la detallada narración de la muerte accidental del rey en unos ejercicios ecuestres con que éste gustaba solazarse. La inversión en el espacio -el rey bajo el noble bruto-

71 "Ad iudices vero seculares, quorum primi reges et infra eos ceteri principes sunt, illud spectat, ut gladio temporali integritatem fidei ac populi christiani unitatem summo studio tueantur, eamque impugnantes acritate sul rigoris coherceant, et quoscumque scismatis seu heresis crimine per ecclesiam dampnatos seu declaratos iusta severitate puniri curent" [A. de CARTAGENA, Defensorium unitatis christianae.(M. Alonso, ed.), Madrid, 1942, pp. 296-297]. Nótese cómo la espadạ viene a ser instrumento jurisdiccional, remitiendo, por tanto a su significación simbólica de ejercicio de la justicia, aunque no se limita al rey. Para la doctrina de las dos espadas, véase Wilhelm LÉVISON, Die mittelalterliche Lehre von den beiden Schwertern, "Deutsches Archiv für Erforschung des Mittelalters", 9 (1951), pp. 14-42; J.A. WATT Spiritual and temporal powers, in The Cambridge History of Medieval Political Thought (J.H. BurNS, ed.), Cambridge, 1988, pp. 370-374.

72 "Depingitur Alphonsus in equo armatus, quia bellicosissimus fuit” (Anacephaleosis, p. 657).

${ }^{73}$ Anacephaleosis, pp. 646-647.

74 "Depingitur itaque sub equo cadens, quia sic casualiter vita $(\mathrm{m})$ finiuit" (Anacephaleosis, $\mathrm{p}$. 659). Si bien parece Cartagena seguir el relato que de este episodio dejó la crónica real [Pero LÓPEZ DE AYALA, Crónica del rey don Juan, primero de Castilla é de León, año X, cap. XX, (C. ROSELL, ed.), BA'E, LXVIII, p. 143b], aporta sin embargo mayores detalles de la caída del rey, que se explican como adición de recuerdos transmitidos oralmente. 
viene a ser la correlativa de las virtudes regias: frente a la estampa bizarra del rey guerrero, el fatal accidente, la muerte infausta, carente de gloria ${ }^{75}$.

Formando parte del armamento de los reyes aparecen los elementos heráldicos, que desempeñan una doble función: caracterizar al monarca en cuestión destacando alguna cualidad relevante que se celebra o bien estructurar la serie genealógica desde el punto de vista cronológico. Alarico, el rey que saqueó Roma, aparece representado con un estandarte, del que no se glosa su específica significación, aunque al asociarse con la espada apuntaría a realzar su condición de conquistador" . Ahora bien, en tanto que "símbolo institucional por excelencia del poder real y de la institución monárquica" ${ }^{77}$, su utilidad como rasgo distintivo quedaba, por tanto, muy limitada -lo que no obsta el que el iluminador del manuscrito N4 utilizara profusamente el motivo heráldico como signo representativo de la institución regia ${ }^{78}$. De hecho, don Alonso ya no vuelve a emplear este signo. Más preciso es el atributo heráldico de Sisebuto, con el que se destaca su celo religioso. Cartagena no duda en recurrir al anacronismo en aras de una mayor eficacia expresiva; así, hace representar el escudo del rey visigodo de forma análoga a la de reyes y caballeros que invocan el auxilio de Santiago ${ }^{79}$, estableciendo, de este modo, un nexo entre la dimensión divinal de la vocación guerrera de la realeza visigoda y la de la castellana.

Las distintas etapas de la serie genealógica se marcan mediante signos heráldicos. Atanarico, el rey que abre la serie dinástica hispana, figura portando un escudo con las armas reales de los godos, del que se indica que se mantiene hasta Rodrigo, el último rey godo ${ }^{80}$. A Pelayo se le asigna el escudo real leonés, pues Cartagena extiende el ciclo del reino leonés desde el primer rey que sucede a los visigodos hasta la unión definitiva de Castilla y León, retrotrayendo la existencia del reino de León en una simplificación del

${ }^{75}$ De hecho, un discípulo de don Alonso, Rodrigo Sánchez de Arévalo, interpretó la muerte accidental de Juan I como castigo divino por no haber santificado éste el dia del Señor [Historia Hispanica, IV, xxii, in Rerum Hispanicarum Scriptores (R. BELL, ed.), p. 404]. Tal vez no sea del todo inoportuno recordar que la caída del caballo cristalizaría en el Barroco en emblema, que en Calderón adquiere enorme potencial semántico (Angel VALBUENA BRIONES, El emblema simbólico de la caída del caballo, in Calderón y la comedia nueva, Madrid, 1977, pp. 88-105). De este modo se pone de manifiesto la aguda intuición iconográfica de Alonso de Cartagena.

76 "Depingitur autem Alaricus cum vexillo alto, enseque nudo in manu eleuata contra cuiusdam imaginem vrbis, propter euersionem quem fecit in vrbem Romanam..." (Anacephaleosis, p. 622). Sobre los estandartes hispanos del Medievo véase Percy E. ScHRAMM, Las insignias de lá realeza en la Edad Media española. Madrid, 1960, pp. 117-125. Para el ámbito castellano, J.M. NIETO SORIA, Ceremonias, pp. 193-194. Desempenaban un destacado papel en las ceremonias de éntronización del Bajo Medievo (Jaime de SALAZAR Y ACHA, La casa del Rey de Castilla y León en la Edad Media, Madrid, 2000, pp. 83-84).

${ }^{77}$ J.M. NIETO SORIA, Ceremonias, p. 193.

${ }^{78}$ Tal vez haya que ver en ello la consecuencia del extraordinario auge que experimentaron las señales heráldicas con los Reyes Católicos (Joaquín YARZA LUACES, Imagenes reales hispanas en el fin de la Edad Media, in Poderes públicos en la Europa Medieval. Principados, Reinos y Coronas. 23 Semama de Estudios Medievales Estella (22-25 julio 1995), Pamplona, 1997, p. 450).

79 “Depingitur Sisebutus [...] scuto vero rubeo, \& cruce alba propter zelum fidei quem habuit. Sic enim depinguntur Reges ac milites Hispanorum, qui inuocantes sanctum Iacobum infideles expugnant" (Anacephaleosis, p. 630).

${ }^{80}$ Anacephaleosis, p. 621. 
pasado hispano que otorga así una continuidad más firme a la serie dinástica que se inicia con Pelayo. Con habilidad argumentativa, don Alonso justifica la anacrónica denominación en el hecho de haber sido León, la capital del reino, la primera ciudad conquistada a los musulmanes ${ }^{81}$.

La serie de los reyes de León se extiende hasta Vermudo III. Con su sucesor en el trono, Fernando I, se inicia la serie de monarcas de Castilla y León. Así, en su representación se indica que en su escudo figuran las armas de ambos reinos, por haber sido su primer rey ${ }^{82}$. Don Alonso tiene buen cuidado de precisar que en el período anterior a la constitución de Castilla como reino, sus gobernantes, lo condes, ejercían un poder soberano, ${ }^{83}$ lo cual no dejaba de ser un mero acto de fe y exaltación castellanista.

En este apartado hay que incluir asimismo aquellos objetos que, aunque utilizados ocasionalmente, se integran perfectamente en el sistema iconográfico elaborado por don Alonso. En primer lugar la cruz, que en Recaredo, a quien se otorga un considerable realce iconográfico, tiene el significado de defensa y exaltación de la fe: se asocia a la erradicación de la herejía arriana ${ }^{84}$. Es de notar que en la glosa correspondiente la referencia a la cruz antecede a la de la espada.

Las llaves constituyen la imagen con que se ensalza al conquistador de una importante ciudad 85 . En los dos casos en que aparece se integran en

81 "Habet in scuto leone $(\mathrm{m})$ depictum rubeum in campo albo, quae sunt arma $\operatorname{Regu}(\mathrm{m})$ Legionis, quia ab eius te $(\mathrm{m})$ pore cessauit in Hispania intitulatio Gothorum \& arma eorum, \& successit intitulatio a regno Legionis, quod forte fuit, quia prima ciuitas quam ab Arabibus occupauit, fuit Legio, \& ex tunc in antea regia ciuitas reputata est" (Anacephaleosis, p. 637). La noticia de la conquista de León por Pelayo venía avalada por la autoridad de Jiménez de Rada quien incluyó este hecho antes de la muerte de Pelayo (De rebus Hispaniae, IV, iv, p. 78b). Lo que hace el Toledano es una simple inferencia del relato que al respecto ofrecía el Tudense, quien al seguir el texto de la Historia Seminense, que amplifica - no con el mero propósito de exornar retóricamente la narración, șino de precisar el significado y alcance políticos de la restauración que se atribuye a Pelayo-, sintió la necesidad de pulir la exposición de su fuente, inçluyendo la muerte del primer rey astur después de referir el matrimonio de Alfonso I con la hija de aquél [Lucas de TUY, Chronicon Mundi, IV, in Hispania Illustrata (A. SCHOTT, ed.), Francfurt, 1608, IV, pp. 72-73 < Historia Silense (J. PÉREZ DE URBEL; A. RUIZ ZORRILLA, eds.), Madrid, 1959, pp. 135-136]. Ahora bien, como Alfonso I conquistó entre otras ciudades León (L. de TUY Chronicon Mundi, IV, p. 73), el Toledano no tuvo reparo en situar dicha conquista durante el reinado de Pelayo. Y en rigor, no dice que éste fuera el conquistador, sino los godos que se le unieron: "Gothi autem [...] ad Pelagium Principem advenerunt et [...] pro fide commori elegerunt. Civitatem etiam Legionem [... primo exercitu invaserunt..." (R. JIMÉNEZ DE RADA, De rebus Hispaniae, IV, iv, p. 78b). Mas al manipular hábilmente la cronología, situando la llegada de Alfonso a Asturias después de la conquista de León, estaba sugiriendo que ésta se debía a Pelayo. Y Alonso de Cartagena así lo interpretó. No obstante, su probidad intelectual le impedía ocultar la referencia a Asturias en la intitulación de los primeros reyes de la Reconquista: "De caetero autem alii Reges nuncupati no(n) fuerunt Reges Gothorum, sed Reges Legionis, vel Asturiarum" (Anacephaleosis, p. 637). Análoga precisión en p. 645.

${ }^{82}$ Anacephaleosis, p. 648.

83 "Nam licet in Castella Comites gubernarent absque recognitione superioris, non tamen titulum regium assumpserunt" (Anacephaleosis, p. 645).

84 “... habet crucem in manu propter expulsionem haeresis Arianae, quam fecit..." (Anacephaleosis, p. 628).

${ }^{85} \mathrm{El}$ motivo de la entrega de las llaves como expresión plástica de la rendición de una ciudad o plaza aparece recurrentemente en los relieves de la sillería del coro de la catedral de Toledo, en la que se esculpió una suerte de crónica de la guerra de Granada (Juan de Mata CARRIAZO, Los relieves de la guerra de Granada en la sillería del coro de la catedral de Toledo, Granada, 1985). Destaca la presencia en ellos del motivo iconográfico de las llaves J. YARZA LUACES, Imágenes reales, pp. 457-458. Véase asimismo Olga PÉREZ MONZÓN, La dimensión artística de las relaciones de conflicto, in La Monarquía como conflicto en la Corona Castellano- 
representación ecuestre, en un contexto icónico, por tanto, de exaltación guerrera. No se trata de símbolo, sino de objeto real. En Fernando I, empero, tienen un valor más bien metonímico; se trata de las llaves que efectivamente exhibió Santiago en su aparición ante el incrédulo peregrino que cuestionaba sus virtudes bélicas y que, puesto que Coimbra fue conquistada gracias a la ayuda del Apóstol, se transfieren al rey conquistador para significar la providencial entrega de la ciudad $^{86}$. Las que figuran en la representación de Fernando III forman parte de una imagen de carácter narrativo: la que capta el momento de la ceremonia de entrega de las llaves de la ciudad ${ }^{87}$.

\section{El atuendo pacífico}

El atuendo pacífico ofrece diversos significados. El obispo de Burgos utiliza dos expresiones para designarlo: "in veste pacifica" e "in veste longa". Aunque suelen asumir significados diferenciados, no se evita la ambigüedad. En efecto, aquélla marca la oposición con el atuendo armado: muy significativamente, en su primera mención, aplicada a la reprentación del rey Sigerico, se añade la carencia de $\operatorname{armas}^{88}$. De este modo, se mostraba la carencia de la virtud esencial de la realeza, la fortaleza de ánimo, de que es expresión conspicua la vocación guerrera, en tanto que a la vestidura larga se le asignan significados específicos. De hecho, la glosa más frecuente a dicha imagen es la cláusula causal "quia bella non gessit". Mas la representación de Leovigildo pone de manifiesto que ambas expresiones pueden resultar sinónimas. Así, este monarca aparece con atuendo pacífico y vestidura larga, porque promulgó leyes, a la vez que empuña una espada desnuda, porque fue belicoso ${ }^{89}$. El atuendo pacífico no significa carencia de virtudes bélicas, sino que se identifica con la vestidura larga, esto es, se neutraliza la oposición que parece mantenerse entre ambas. De hecho, en la imagen de Ordoño I se añade al

Leonesa (c. 1230-1504) (J.M. NIETO SORIA, dir.) Madrid, 2006, pp. 567-568.

86 "Depingitur in equo armatus sancto Iacobo claues ciuitatis Colimbriae tradente..." (Anacephaleosis, p. 648). En este punto, don Alonso se aparta de la exposición del Toledano, que omite el detalle de las llaves en su relato de la aparición (De rebus Hispaniae, VI, xi, p. 126a). $Y$ es que, en efecto, a partir del capítulo LV, sigue don Alonso preferentemente una fuente vernácula (L. FERNÁNDEZ GALLARDO, Alonso de Cartagena, p. 291). Las llaves exhibidas por Santiago reaparecen en la Estoria de España de Alfonso X [Primera Crónica General, cap. 807 (R. MENÉNDEZ PIDAL, ed.), Madrid, 1977, II, p. 487b]. Para la evolución de la leyenda del auxilio de Santiago en la toma de Coimbra, véase L. FERNÁNDEZ GALlARDO, Santiago Matamoros en la historiografía hispanomedieval: origen y desarrollo de un mito nacional, "Medievalismo", 15 (2005), pp. 139-174.

87 “Depingitur Fernandus armatus in equo prope ciuitatem Seuilliam, quodam Arabe dante illi claues, quia ciuitas illa per longam \& obstrictam obsidionem ab eo afflicta in deditione eius deuenit" (Anacephaleosis, p. 654). Y en efecto, la Estoria de España refiere cómo los moros entregaron las llaves de ciudad al rey Fernando (Primera Crónica General, cap. 1124, t. II, p. 767a).

88 "Depingitur in veste pacifica absque cultu armorum, quia bella non gessit" (Anacephaleosis, p. 622).

${ }^{89}$ Anacephaleosis, p. 628. La representación de de Gundemaro presenta análogo caso de compatibilidad de atuendo pacífico y espada empuñada: "Depingitur in veste pacifica cu(m) ense in manu propter bella quae gessit" (Anacephaleosis, p. 629). 
atuendo bélico una capa larga ${ }^{90}$, combinación anómala en la que el término “cappa longa" resulta excepcional, ajena al sistema iconográfico.

Ahora bien, la vestimenta pacífica no expresa necesariamente carencia de vocación guerrera; simplemente puede expresar que el rey en cuestión mantuvo la paz ${ }^{91}$. Por otra parte, dada la importancia que se concede al modo de morir de los reyes, puede darse el caso de que la representación se centre en este aspecto, antes que en destacar las aptitudes bélicas, por lo que el atuendo pacífico podía resultar más adecuado para tal fin, como pone de manifiesto la imagen de Turismundo ${ }^{92}$. La vestidura pacífica no significa carencia de cualidades guerreras, no es símbolo de cualidades regias, sino elemento real de la escena representada, la muerte alevosa que tuvo.

La vestimenta larga al asociarse generalmente a la pacífica parece constituir una especificación de ésta, presentando significados diversos, partiendo del genérico de autoridad ${ }^{93}$. Así, en primer lugar, representa al legislador. Así se pone de manifiesto en la imagen de Leovigildo, donde denota autoridad y madurez ${ }^{94}$. Tal vez don Alonso quisiera sugerir la similitud con el atuendo sacerdotal. De este modo, diríase que en la base de este motivo iconográfico se halla una reflexión incluida en su Duodenarium acerca del decoro del rey legislador, que se asimila a la dignidad sacerdotal ${ }^{95}$. El carácter sacral de la vestimenta larga se pone de manifiesto en la imagen de Alfonso II, asociada a un hecho sobrenatural, pues con ella se quiere perpetuar el recuerdo del milagro de la cruz $^{96}$.

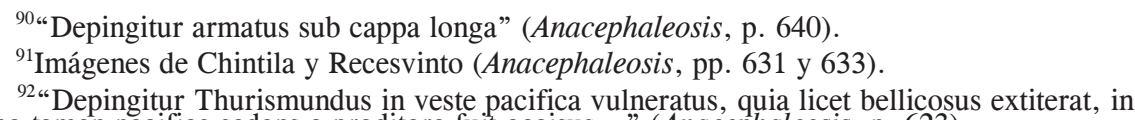
domo tamen pacifice sedens a proditore fuit occisus..." (Anacephaleosis, p. 623).

${ }^{93} \mathrm{La}$ glosa a la imagen de Teodorico es terminante al respecto: "Depingitur senex in veste longa, quia in pace obiit grandaeuus aetate \& magnae auctoritatis" (Anacephaleosis, p. 625). Aunque la imagen de Mauregato (p. 639) revela que podía adquirir asimismo un valor negativo 94 “... depingitur in veste pacifica ac longa, quia leges co(n)didit, quarum promulgatio autoritatem \& maturitatem desiderat..." (Anacephaleosis, p. 628).

${ }_{95}$ "Quid enim si legum sciencie operam dantes per jurisconsultum sacerdotes vocantur? Nonne ipsi jurum conditores sacerdotum honestatem seruare congruentissimum est?" (A. de CARTAGENA, Duodenarium, Archivo de la Catedral de Burgo de Osma, cód. 42, f. 29 v. b). Cfr.: "Cuius merito quis nos sacerdotes appellet: iustitiam namque colimus..." (Dig., 1, 1, 1).

96“Depingitur hic Alphosus senex in veste longa \& honesta, angelis sibi dantibus crucem quam fabricauerant..." (Anacephaleosis, p. 640). Ahora bien, al privar don Alonso al rey Alfonso de atuendo bélico diríase que estaba cuestionando tácitamente -el silencio sobre la ayuda que Bernardo del Carpio prestó al rey astur es sumamente elocuente- la tradición de la victoria obtenida sobre Carlomagno y Roldán, que introduce del siguiente modo: "Hic dicitir deuicisse Carolum Magnum..." (p. 640). Aunque tal tradición venía avalada por la autoridad del Toledano (cfr. De rebus Hispaniae, IV, x, pp. 83-84), quien recoge la leyenda épica de Bernardo del Carpio, don Alonso parece ponerla en cuarentena. Por otra parte, sitúa la figura de este personaje legendario en el reinado de Alfonso III, contra el cual lo presenta rebelde (p. 641). Acerca de esta tradición, hay que tener en cuenta que la victoria de Bernardo en Roncesvalles era incidental en el ciclo primitivo; solo adquirió amplio desarrollo en los historiadores del siglo XIII [William J. ENTWISTLE, The 'Cantar de gesta' of Bernardo del Carpio "Modern Language Review" XXIII (1928), p. 307]. Sobre esta cuestión, véase asimismo Jacques HORRENT, $L$ histoire légendaire de Charlemagne en Espagne in Charlemagne et l'épopée romane. Actes du VIr Congrès International de la Societé Rencesvals, Paris, 1978, I, pp. 145-146. Sobre la cruz de Ȧlfonso II, véase Gonzalo MENENDEZ PIDAL, El lábaro primitivo de la Reconquista. Cruces asturianas y cruces visigodas, in Varia Medievalia I, Madrid, 2003, p. 183. 
El vestido largo adquiere en la representación de Alfonso X un significado específico: la erudición y el saber astrológico ${ }^{97}$. Es posible que don Alonso estuviera sugiriendo el atuendo académico, la ropa talar con que se señalaba la autoridad de los docentes ${ }^{98}$. Ahora bien, no deja de ser ambigua la caracterización de este monarca. Puesto que se había mencionado su obra legislativa, extraña que la indumentaria asignada no significara condición de legislador. Como el epíteto "astrólogo" no dejaba de presentar connotaciones negativas $^{99}$, la imagen del rey Alfonso parece oscilar entre la dignidad académica y la sospecha herética del astrólogo ${ }^{100}$. Mas al presentarlo en posición sedente -"sedens" (p. 655)-, se estaba sugiriendo la autoridad que le correspondería como gran legislador.

Asimismo, Cartagena se vale de esta imagen para resaltar otro aspecto relevante de la biografía del monarca, las circunstancias de su muerte. Dada la relevancia que se otorgaba al modo de morir de los monarcas, era lógico que se destacara el óbito natural frente a las numerosas muertes violentas que padecieron los reyes visigodos ${ }^{101}$.

Como variantes de la vestimenta pacífica cabría incluir otras modalidades del atuendo real. En la línea de la indicación de las circunstancias del óbito regio se sitúa la vestimenta infantil, con que quedaba netamente definida la representación del monarca como niño que así moría ${ }^{102}$. Asimismo, se recurre a una prenda exótica para expresar el filoarabismo del rey que concluyó ignominioso pacto con los musulmanes, Mauregato ${ }^{103}$. Valor excepcional presenta el autendo fúnebre con que se representa a Rodrigo, que destaca no solo la infausta y luctuosa derrota ante los musulmanes, sino el contraste con el lujoso e impropio atavío con que acudió a la batalla ${ }^{104}$.

97 “Depingitur Alphonsus sedens indutus veste longa, vt mos peritorum, habens librum in manu, quia scientificus fuit, \& communiter vocatus Astrologus" (Anacephaleosis, p. 653).

${ }^{98}$ Ciertamente, la ropa larga no era infrecuente en el atuendo masculino del siglo XV, pues entre las prendas para ir a cuerpo, además del jubón, había "vestidos cuyo largo variaba entre la rodilla y el tobillo" (Carmen BERNIS MADRAZO, Indumentaria medieval española, Madrid, 1956, p. 37).

${ }^{99}$ Como pone claramente de manifiesto el capítulo que dedica Sánchez de Arévalo en su menciọnada obra histórića al dar razón de dicho epíteto (Historia Hispanica, IV, v, pp. 376-378). Análisis de la estimación de este monarca en la historiografía cuatrocentista en Jean-Pierre. JARDIN, La figure du roi Alphose $X$ chez quelques chroniqueurs du XV siècle, "Cahiers de Linguistique Hispanique Médiévale", 20 (1995), pp. 75-96 (no incluye la Historia Hispanica).

${ }^{100}$ Consideraciones sobre la posición de la astrología en el saber del Medievo en Alain de LiBERA, Penser au Moyen Age, París, 1991, pp. 246-298.

${ }^{101}$ Así, en las imágenes de Eurico y Costa (Anacephaleosis, pp. 624 y 635).

102 "Depingitur autem puer, \& in veste puerili, quia puer obiit" (Anacephaleosis, p. 630).

103 "Depingitur Mauracatus in veste longa, \& coopertus chlamyde iuxta morem Arabum, quia cum Arabes turpem amicitiam fecit" (Anacephaleosis, p. 639).

104“Depingitur autem Rodericus sub luctuosa veste, yt qui superbe cum pomposis insignibus ad praelium processit, infoeliciter victus sub nigra veste miserabiliter depingitur. (Anacephaleosis, p. 636). Ya la fuente canónica había resaltadọ el lujoso aparato con que se presentó Rodrigo para combatir a los sarracenos: "Rex autem Rodericus cum corona aurea et vestibus deauratis a duobus mulis in lecto eburneo ferebatur, ut Gothorum Regum dignitas exigebat" (R. JIMÉNEZ DE RADA, De rebus Hispaniae, III, xx, p. 67a). El detalle, introducido por vez primera con esta obra - ausente en los detallados relatos de la Historia Seminense y del Chronicon Mundi del Tudense-, ciertamente más novelesco que histórico - ¿efectivamente se creía que era así el ceremonial regio de los visigodos?-, revela una fuente legendaria. Precisamente con el Toledano, la leyenda de 
Asimismo excepcional es el capuchón monacal con que se hace cubrir a Vamba, para indicar que acabó sus días como monje, tras renunciar al trono. Es de notar la incongruencia del atuendo bélico y la capucha ${ }^{105}$, que se resuelve si se tiene en cuenta su carácter rigurosamente simbólico, pemitiéndose su combinación como elementos de un sistema de expresión.

Asociados a la indumentaria pacífica Alonso de Cartagena dispone otros atributos que completan el perfil de la realeza hispana. Con carácter único aparece la diadema, signo de la condición imperial, en la representación de Alfonso VII. Figura asociada a la posición sedente, cuya conjunción apunta a destacar le posición preeminente de este monarca ${ }^{106}$. La elección de la diadema como signo imperial tal vez remonte a su experiencia diplomática en la corte del emperador Alberto II; sin embargo, era un signo familiar en el ámbito hispánico -al menos en el entorno burgalés-, dado que en el Hospital del Rey, uno de los grandes centros que atendían a los peregrinos de Santiago ${ }^{107}$, se esculpió una figura que representaba a Alfonso VII con diadema. De Alfonso X se indica que fue elegido emperador de Romanos y, sin embargo, la imagen con que se quiere perpetuar su recuerdo elude esta circunstancia. Ello se debe a que los contenidos de la dignidad imperial ostentada por ambos monarcas es diferente. El del primero apunta a la preeminencia del rey castellano en el ámbito hispánico, como se recuerda en la intitulación ("Imperator Hispaniae") ${ }^{108}$, mientras que el del segundo se refiere a la institución cuyas aspiraciones a un poder ecuménico suscitaban los recelos de quien sostuviera con firmeza la soberanía de Castilla ${ }^{109}$.

Rodrigo adquiere otro sesgo argumental (Ramón MENÉNDEZ PIDAL, Floresta de leyendas heroicas. Rodrigo, el último godo, I (La Edad Media), Madrid, 1973, pp. LVII-LXV).

105 "Depingitur Bamba armatus, sed coopertus cucullo monachali, quia gloriose bellum contra Paulum \& fautores regnans gessit, sed in fine monachus effectus ab hac luce substractus est" (Anacephaleosis, p. 633).

106 "Depingitur Alphonsus cum diademate imperiali, \& sedens propter eminentiam dignitatis, quia Imperator vocatus est" (Anacephaleosis, p. 650). No es casual que este monarca se hiciera representar en su sello sentado en un trono de banco, conforme al modelo del sello imperial (P.E. SCHRAMM, Las insignias, p. 30). Conviene destacar que don Alonso elude el globo como marca icónica de la dignidad imperial, aun cuando en el sello mencionado se ha identificado dicho símbolo (P. E. SCHRAMM, Sphaira - Globus - Reichsapfel. Wanderung und Wandlung eines Herrschaftszeichens von Caesar bis zu Elisabeth II, Stuttgart, 1958, p. 125). Y es que no ignoraba su significado de poder ecuménico, valor, por otra parte, reivindicado por los emperadores alemanes del Bajo Medievo (Ibídem, p. 99). Y sin embargo, el iluminador del manuscrito N lo añadió en la representación de Alfonso VIII (BNM, ms. Vit..19-2, f. 31 v. ), más que por prurito ornamental, tal yez parạ legitịmar históricamente las aspiraciones imperiales de Carlos $\mathrm{V}$, a cuya esposa se dedicó tan lujoso ejemplar, mostrando así las raíces hispanas de la dignidad imperiảl.

${ }^{107}$ Por tanto, con un enorme potencial difusor de la iconografía regia allí desplegada. Sobre el hospital y su contexto de peregrinación, véase Luis VÁZQUEZ DE PARGA; José María LACARRA; Juan URÍA RIU, Las peregrinaciones a Santiago de Compostela, t. II, Madrid, 1948, pp. 188-192. $\mathrm{Se}$ da la circunstacia de que don Alonso, al promover las obras de mantenimiento de dicho hospital, hizo que en la diadema con que aparecía representado Alfonso VII se esculpieran las insignias regias para que no fuera confundido con cualquier emperador extranjero, tal y como refiere el propio prelado burgalés (Duodenarium, f. 5 v. a).

${ }^{108}$ Anacephaleosis, p. 650. El obispo de Burgos daría detallada cuenta de los contenidos de la dignidad imperial de Alfonso VII en su Dudoenarium (f. 5 v.). Para la relación entre idea imperial y hegemonía peninsular, véase H.J. HÜFFER, Das Spanische Kaisertum der Könige von Leon-Kastilien, Münster, 1931 pp. 35-50; Alfonso GARCİA GALLO, El Imperio medieval español, "Arbor", 18 (1946), pp. 218-220.

${ }^{109}$ La prevención del prelado burgalés hacia el Imperio se pone claramente de manifiesto en su Duodenarium (ff. 2 v.-5 r.). 
Asimismo excepcional resulta la imagen sedente. Cartagena la concibe asociada a la diadema imperial para expresar la eminencia de la dignidad imperial de Alfonso VII. Mas incurre en contradicción al indicar su carácter único ${ }^{110}$, pues aparece de nuevo en la representación de Enrique III. En ésta se presenta, a su vez, vinculada a otro objeto, el trono, únicamente mencionado en esta ocasión. La expresión formularia de la glosa correspondiente es amplificada para subrayar la excelencia de este rey -de cuya admiración dejara un testimonio elocuentísimo en su Duodenarium ${ }^{111}$. Dicha amplificación venía a precisar el valor simbólico de la posición sedente, que se erige así en imagen de la excelencia y solemnidad regias ${ }^{112}$, lo que resulta significativo, dado que el trono había perdido su virtualidad como signo de la realeza, en favor del pendón real ${ }^{113}$.

\section{Referencias a la edad}

En ocasiones se hace referencia a la edad de los reyes como elemento icónico. Viene a marcar la excepción a lo que se consideraba como esperanza de vida normal ${ }^{144}$, tanto por exceso como, caso más corriente, por defecto. Para su expresión plástica puede aparecer combinada con la vestimenta, en su variante pacífica, o bien independiente. La primera opción se aplica a la niñez ${ }^{115}$ y a la vejez, porque tales edades disponían de indumentaria específica, de ahí que la vestimenta tuviera valor distintivo a tal efecto. La segunda corresponde a la adolescencia, a la temprana juventud; en tal caso, la indicación apuntaría a una caracterización fisiognómica típica de tal edad.

Solo se hace mención de un monarca provecto, Teodorico ${ }^{116}$. La senectud del rey se erige así en signo de autoridad. En cuanto a las referencias a la muerte prematura, se suelen indicar los dos tramos vitales correspondientes, pueritia y adolescentia. En la niñez murió Recaredo II: era poco menos

110 "Nullus autem aliorum Regum sedens depingitur praeter istum, propter singularitatem tituli imperialis" (Anacephaleosis, p. 650).

${ }^{111}$ Donde Enrique III y su hermano Fernando de Antequera encarnan la ejemplaridad regia (Duodenarium, ff. 28 v. a-31 v. b). Tan importante documento no es tenido en cuenta en la relación de testimonios sobre este rey aportados en Emilio MITRE FERNÁNDEZ, Una muerte para un rey. Enrique III de Castilla, Valladolid, 2001, pp. 29-35. Se ha destacado que las limitaciones físicas de Enrique III, así como las de Carlos V de Francia, contribuirían a forjar el ideal del "rey de despacho" (E. MITRE FERNÁNDEZ, Muerte y memoria del Rey en la Castilla Bajomedieval, in La ldea y el sentimiento de la muerte en la historia y arte de la Edad Media, Santiago de Compostela, 1992, t. II, p. 25).

112 "Depingitur Enricus in apparatu honestissimo regali sede(n)s in cathedra..." (Anacephaleosis, p. 660).

${ }^{113}$ P.E. SCHRAMM, Las insignias, pp. 32-33.

${ }^{114}$ Véase a este respecto E. Mitre FERNÁNDEZ, Una muerte, pp. 43-45.

${ }^{115}$ Resulta notable la atención prestada a la representación de los reyes niños en una época en que escasean las imágenes de la niñez, debido precisamente a la indiferencia sentida hacia esta etapa de la vida (véase al respecto Philippe ARIÉS, L'enfant et la vie familiale sous l'Ancien Régime, París, 1973, pp. 53-74; asimismo, Peter BURKE, Visto y no visto. El uso de la imagen como documento histórico Barcelona, 2001, pp. 131-135). En concreto sobre la vestimenta específica del niño, véase Ph. ARIÉS, ob. cit., pp. 75-89.

116 "Depingitur senex in veste longa, quia in pace obiit grandaeuus aetate, \& magnae auctoritatis..." (Anacephaleosis, p. 625). 
que obligado presentarlo de esta guisa, pues la fuente canónica señalaba que nada digno de ser recordado realizó dado su corto reinado ${ }^{117}$. Como adolescentes aparecen representados Liuva II y Sancho III ${ }^{118}$. En la misma categoría habría que incluir Tulgas, en cuya imagen se indica simplemente que ha de aparecer joven $^{119}$.

\section{La muerte violenta}

Completamente independiente del atuendo es el gesto con que se representa la muerte violenta del rey. Se observa una tendencia a la adopción de una expresión formularia, especialmente en la serie de los monarcas visigodos, regularidad que pone de manifiesto su condición sistemática. Cartagena utiliza tres términos: mortuus, occisus y vulneratus -nominativos que aparecen en función de complemento predicativo. El primero es el más genérico, en tanto que los otros dos denotan la violencia sufrida por el monarca representado. La cláusula causal que da razón de la imagen especifica las circunstancias de la muerte. Este gesto puede aparecer como único atributo ${ }^{120}$.

Puesto que el tipo de muerte no condiciona necesariamente la valoración del rey, este gesto puede combinarse tanto con imágenes bélicas como con pacíficas. En el primer caso es lo más frecuente que la muerte tuviera lugar en el campo de batalla, circunstacia ésta que no deja de consignarse $^{121}$. La adición de la muerte violenta al atuendo armado no necesariamente implicaba exaltación de las virtudes bélicas, sugiriendo el más alto sacrificio que el guerrero podía ofrecer, como revela precisamente el primer uso de esta combinación ${ }^{122}$, pues la imagen del rey abatido no era precisamente celebrativa.

\section{La imagen descriptiva y narrativa}

En ocasiones, para la faceta que quería trasmitir a la posteridad Alonso de Cartagena, debido a su especificidad, el repertorio de atuendos y gestos del sistema icónográfico se revelaba insuficiente. De ahí que recurriera a indicaciones icónicas que, en la medida en que la imagen representaba

${ }^{117}$ R. JIMÉNEZ DE RADA, De rebus Hispaniae, II, xvii, p. 41a > Anacephaleosis, p. 630.

${ }^{118}$ Anacephaleosis, pp. 629 y 656.

119 “Depingitur iuuenis [...] quia iuuenis obiit...” (Anacephaleosis, p. 632).

${ }^{120}$ Imagen de Teodorico (Anacephaleosis, pp. 623-624).

${ }^{121}$ Imágenes de Teodoredo, Alarico y Amalarico (Anacephaleosis, pp. 623, 624 y 625).

${ }^{122}$ Imagen de Ataulfo: “... depingitur sub armatu cultu, quia se armis dederat, in terram tame $(n)$ postratus \& mortuus, quia fuit occisus" (Anacephaleosis, p. 622). Se observa una aparente incoherencia icónica, si se atiende a la noticia de su muerte: ${ }_{\text {inter familiares fabulas iugulatus..." Difícilmente podía hallarse armarcinonam fuit }}$ inter familiares fabulas iugulatus..." Difícilmente podía hallarse armado en semejante situación, presentaba una mayor "literalidad". 
elementos de la realidad designada verbalmente, presentaban un valor descriptivo o narrativo.

\section{6.a. Sobre la muerte del rey}

La mayor parte de las imágenes descriptivas o narrativas se refieren a las circunstancias de la muerte del rey. Y es que el interés historiográfico que ofrecía el óbito regio exigía atender a sus espefícicas circunstancias ${ }^{123}$, que en ocasiones, en la medida en que condicionaba su estimación, constituía la faceta más destacada del monarca, aquella que el obispo de Burgos quería transmitir a la posteridad. Se observa en la serie de los reyes leoneses y castellanos una tendencia al desarrollo anecdótico; en la de los visigodos, por el contrario, una mayor uniformidad en las referencias, una regularidad en la captación del detalle relevante que diríase apunta a una sistematización.

En efecto, al indicarse la representación de la muerte violenta se menciona el arma con que fue abatido el rey en cuestión: maza, lanza, espada y puñal son los instrumentos del regicidio ${ }^{124}$. Si don Alonso dispone de información al respecto, indica el modo preciso como fue agredido el rey: no contento con la sugerencia genérica, incluye los pormenores que sobre faceta tan destacada de la biografía regia ofrecían las fuentes. Así, en la imagen de Teudisclo, se le hace representar junto a la mesa, para sugerir el banquete en que fue asesinado ${ }^{125}$. En el caso de Teudis, la maza con que aparece abatido, frente a la espada que figura en el relato de Jiménez de Rada, viene a sugerir el instrumento innoble que no podía blandir sino un simple histrión ${ }^{126}$. Otros pormenores son aducidos para perpetuar la imagen de un monarca despojado de la dignidad regia, como en el caso de Vitiza, ciego y aherrojado, miserable estado en que acabó sus días ${ }^{127}$. Análogo es el de Alfonso IV, a quien cegó y encarceló su hermano Ramiro II, mas frente al detalle dramático de las

${ }^{123}$ Sobres éstas, desde un punto de vista médico, aunque referido a la realeza inglesa, véase Clifford BREWER, The Death of Kings. A medical history of the Kings and Queens of England, Londres, 2005, pp. 6-12.

${ }^{124}$ Maza para la imagen de Teudis (Anacephaleosis, p. 626); lanza para las de Vermudo III (p. 645) y Sancho II (p. 648); espada para las de Liuva (p. 629), Viterico (p. 629) y Ordoño I (p. 643); puñal para las de Aquila (p. 626) y Fruela (p. 638); saeta para la Aifonso V (p. 644).

125 "Depingitur cum in mensa prandet, occisus" (Anacephaleosis, p. 626). Es de notar cómo Cartagena amplifica aquí el relato del Toledano (De rebus Hispaniae, II, xii, p. 37a) -quien a su vez, retoma fielmente el de San Isidoro [Historia Gothorum, ápud Enrique FLóREZ España Sagrada, t. VI, p. 497)-, en sentido moralizante, con lo que la nota "pintoresca" del banquete adquiere pleno sentido ejemplarizante. Por otra parte, el significado de la anécdota se precisa desde la perspectiva de la acusada dimensión social que tenían banquetes y comidas en el Medievo (véase al respecto Bruno LAURIOUX, Manger au Moyen Age, París, 2002, pp. 185-211).

${ }^{126}$ En este punto el obispo de Burgos se aparta de la fuente canónica para seguir el relato más dramático de la Estoria de España. El audaz regicida que se finge loco fue transformado por los historiadores alfonsíes en albardán, término que precisamente utilizạ Cartagena (R. JIMÉNEZ DE RADA, De rebus Hispaniae, II, xil, pp. 36b-37a > Primera Crónica General, cap. 453, I, p. 255b).

127 “Depingitur Vitiza absq(ue) oculis, \& cum compedibus ferries, quia caecus \& incarceratus $\operatorname{vita}(\mathrm{m})$ exuit" (Anacephaleosis, p. 634). 
cadenas, en esta imagen Cartagena opta por el atuendo pacífico (vestimenta larga), para resaltar su falta de iniciativas bélicas ${ }^{128}$.

En ocasiones, don Alonso concede tal interés a las circunstancias del óbito regio que la imagen acumula pormenores que sugieren un desarrollo narrativo. La imagen de Enrique I, muerto en la niñez, pretende perpetuar su carácter accidental: hábilmente se presenta al niño doliéndose del golpe que le causó la muerte ${ }^{129}$. Así, al sugerirse dos momentos, el representado, impacto de la teja y, por asociación con el texto precedente, su resultado, la muerte, se apuntaba un conato narrativo. Aparentemente anecdótica es la muerte de Favila, víctima de un fatal accidente cinegético ${ }^{130}$, mas la imagen se torna tácita crítica de los excesos venatorios de los reyes. Un mayor calado político, sin embargo, presenta la representación de Pedro I, que no casualmente es la que ofrece un mayor desarrollo narrativo. Es ésta la única imagen de la Genealogía, cuya glosa contiene verbos de acción sucesivos en el tiempo, que generan de este modo una secuencia narrativa: lucha, caída y muerte. Precisamente por ello esta indicación iconográfica carece de cláusula causal, pues la imagen era lo suficientemente explícita como para necesitar glosa. Pero es más, no solo se quiere expresar gráficamente el fratricidio sobre el que se alzó la dinastía Trastámara, sino presentar la escena con pormenores descriptivos, de ahí la indicación del castillo en lo alto de un monte con que se figura el fatídico lugar ${ }^{131}$. La imagen de Pedro I va, por tanto, más allá de la mera representación del regicidio; diríase que constituye una recreación de una escena que decidió el destino de la realeza castellana.

\section{6.b. Otros aspectos}

Resulta sumamente significativa la imagen de Aurelio. Este rey no fue objeto, sino sujeto de fratricidio, lo que suscitó la reprobación sin matices del prelado burgalés; a tal punto, que la imagen que iba a perpetuar su recuerdo pretende sugerir el gesto de vergüenza por tal crimen: el rostro vuelto, ocultándose, cual nuevo Caín ${ }^{132}$. Si bien pudiera parecer una tácita crítica del

\footnotetext{
128 "Depingitur Alphonsus caecus in veste longa, quia bella non gessit, \& caecus mortuus est" (Anacephaleosis, p. 642).

129 "Depingitur puer [...] \& manu posita in capite ad ostendendum dolorem illati vulneris..." (Anacephaleosis, p. 653).

130 “... depingitur cum vrso pugnans, quia vrsi dentibus \& brachiis depressus obiit" (Anacephaleosis, p. 638).

131 “Depingitur Petrus cu(m) Enrico pugnans, \& in terram cadens ab eo occisus, \& in cacumine montis castellum positum per quod Montiel figuratur". (Anacephaleosis, p. 657). No necesariamente tenía don Alonso que haber leído la cronica de Ȧyala, pues tal escena formaba parte de la memoria colectiva de los castellanos de su tiempo.

132 "Depingitur Aurelius versa facie, quia fratrem suum iniuste occidit, \& quasi ex verecundia de ta(n)to flagitio faciem no(n) monstrans, vt alter Cain verecundans ob Abel occisum" (Anacephaleosis, p. 639).
} 
fratricidio de Montiel, el adverbio "iniuste" viene a aclarar que éste se hallaba en cierta medida justificado ${ }^{133}$.

En otras ocasiones, Cartagena pretendía captar un hecho destacado del monarca en cuestión. Presentan un claro carácter narrativo las imágenes de Alfonso II, Fernando I y Fernando III, solo que se construyen con elementos que forman parte del sistema iconográfico. En esa misma línea celebrativa se sitúa la imagen de Ramiro I, en la que al atavío bélico se añade el gesto durmiente, que sugiere la providencial aparición de Santiago en auxilio de las apuradas huestes cristianas ${ }^{134}$. No era incongruente tal conjunción de atributo y gesto, en la medida en que, como señalara Juan de Salisbury, había que confiar en los sueños del rey si se trataba de asuntos públicos ${ }^{135}$. El sueño representado, antes que destacar un favor sobrenatural al individuo, apuntaría a su naturaleza de atributo regio. Y es que la escena así concebida no podía ser más señalada, pues en agradecimiento al Apóstol por la victoria obtenida sobre los moros en Calahorra, el rey Ramiro I concedió los denominados Votos de Santiago, favor al que se mostraba especialmente sensible don Alonso dada su condición de deán compostelano. El obispo burgalés omite, sin embargo, la representación del Apóstol, tal vez porque ésta se reservaba para la imagen de Fernando I.

En dos imágenes figuran indicaciones sobre el aspecto físico del monarca. En la de Sancho I, se añade a la vestimenta pacífica la complexión obesa, cuya función no es otra que la de perpetuar la razón de su apodo, "Grossus"136. Carácter más específico ofrece la de Vermudo II, que no hace sino ilustrar las circunstancias de su muerte, causada por la gota ${ }^{137}$. No se espere, pues, atisbo alguno de individualización. En ambos casos se trata de

\footnotetext{
${ }^{133}$ Alonso de Cartagena no tercia en la polémica en torno a la licitud del regicidio que se levantó en el concilio de Constanza. Con relación a la muerte de Pedro I a manos de su hermanastro, no había dejado de consignar que el rey apodado el Cruel quiso matar a Enrique de Trastámara (Anacephaleosis, p. 657), aunque no le restara legitimitad alguna en el cómputo de años de su reinado (p. 658).

134 "Depingitur hic Ramirus dormie(n)s in castris armatus, eo quod sic dormienti apparuit ei S. Iacobus" (Anacephaleosis, p. 640).

${ }^{135}$ Juan de SAlisbury, Policraticus, I, xv (M.A. Ladero; M. Garçía; T. Zamarriego, eds.), Madrid, 1984, p. 169. Si bien no hay datos que avalen el conocimiento de la obra de Salisbury por parte de Alonso de Cartagena, su discípulo Sánchez de Arévalo ya cita ampliamente el Policraticus en su Suma de la política (M. PENNA, ed.), BAE, t. CXVI, pp. 269b, 270b, 278b, $292 b, 296 b)$.

136“Depingitur Sancius in veste pacifica, \& grossus corpore, quia magna pinguedine occupatus erat" (Anacephaleosis, p. 643).

137 “. .. depingitur cum malis pedibus, \& baculo in manu, quia propter podagram incedere libere no(n) valebat" (Anacephaleosis, p. 644). En este punto don Alonso se aparta de la fuente canónica, pues el Toledano, no alude a la enfermedad de Vermudo II (De rebus Hispaniae, V, xvii, p. 1 10a). Pudo tomar el dato tanto del Tudense (Chronicon Mundi, III, p. 89) como de cualquier derivạdo de la Estoria de España (Primera Crónica General, cap. 757, t. II, p. 451a). Pero es más, mientras que ambas fuentes destacaban el arrepentimiento y acendrada piedad con que concluyó sus días el rey leonés, Cartagena omite toda referencia a tan extremadas muestras de penitencia, con lo que el sentido de la enfermedad cambiaba de modo radical: de signo mortificante que realzaba la piedad exhibida pasaba a sugerir su condición expiatoria de las iniquidades perpetradas. Y es que el dolor era concebido en el Medievo como castigo del pecado, a la par que degradante (Georges DuBY, Réflexions sur la douleur physique au Moyen Age, in Mâle Moyen Age. De l'amour et autres essais, París, 1988, p. 206). Y sin embargo, Ordoño I murió asimismo de gota, pero se le reserva una imagen celebrativa, armado (Anacephaleosis, $\mathrm{p}$. 640).
} 
atributos relativos a la salud que se consideraban atingentes a la dignidad regia. En el caso de Vermudo, la enfermedad, al referirse precisamente a continuación de los intentos de atentar contra el arzobispo de Santiago y el obispo de Oviedo. La enfermedad de la gota constituiría una suerte de castigo divino por las inicuas maquinaciones contra ambos prelados ${ }^{138}$.

\section{IMÁGENES DE LA REALEZA}

Con tan sencillo sistema iconográfico Alonso de Cartagena había elaborado un repertorio de gestos representativos de los atributos de la realeza, esto es, de cualidades de los monarcas que tenían un significado institucional. Su finalidad no era ni mucho menos captar la individualidad del personaje, sino transmitir una caracterización que conllevaba un juicio de valor de sus cualidades no tanto personales cuanto regias ${ }^{139}$. Y sin embargo, en una reflexión surgida a propósito del quehacer historial, don Alonso había limitado el oficio del cronista a la mera consignación de los hechos, privándole de la facultad de juzgarlos ${ }^{140}$. Las imágenes que componen el sistema iconográfico de la Genealogía están marcadas, con todo, de modo valorativo en la medida en que éste se fundamenta en una concepción de la realeza largamente meditada por el prelado burgalés en su dilatada vida de curial al servicio de la corona castellana.

A pesar de su ascendiente intelectual y moral en la corte de Juan II, Alonso de Cartagena no escribió ninguna obra específica sobre la figura del rey al modo de los espejos de príncipes, a diferencia de su discípulo Sánchez de Arévalo, que dedicaría a Enrique IV su Vergel de príncipes. Sin embargo, su amplia producción literaria y publicística contiene numerosas consideraciones al respecto. A pesar de la flexibilidad que se observa en su pensamiento político, debido a las circunstancias precisas en que se gestó cada una de sus obras, escritas en su mayor parte al dictado de urgentes necesidades ${ }^{141}$, en lo relativo al oficio regio se observa empero una coherencia en sus planteamientos, que obedece a arraigadas convicciones sobre la naturaleza del poder real y, especialmente, sobre la misión que creía asignada a la realeza castellana. Su más acabado planteamiento sobre la figura del rey se halla en una obra redactada en plena madurez y dedicada a su amigo Pérez de Guzmán, el Duodenarium. Al responder a la cuestión planteada por el señor de Batres

\footnotetext{
${ }^{138}$ Para los distintos significados de la enfermedad del rey, véase E. Mitre FernánDEZ, Una muerte, pp. 49-57.

${ }^{139}$ Esto se pone claramente de manifiesto en la imagen de Enrique II. Si bien se deja constancia de su temple belicoso, se le hace representar con vestimenta pacífica porque no llevó a cabo guerras contra los moros' (Anacephaleosis, p. 658).

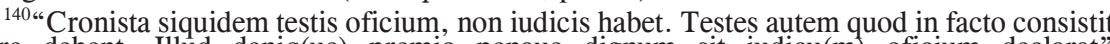
edicere debent. Illud deniq(ue) premio penaue dignum sit iudicu(m) oficium declarat" (Duodenarium, f. 17 v. a).

${ }^{141}$ Sobre esta faceta del pensamiento político de Cartagena, véase L. FERNÁNDEZ GALLARDO, Alonso de Cartagena, pp. 322-323.
} 
acerca de quién fue el mejor rey hispano de entre los precedentes en bondad y virtud, procedió a una precisa delimitación del tema: la precisa definición de las virtudes propias del rey, aquellas que deciden su excelencia. La extensión y el rigor expositivo que caracteriza el quehacer intelectual de Cartagena hacen de tales consideraciones un breve tratado sobre la figura del rey, una suerte de espejo de príncipes de profunda inspiración aristotélica.

El rasgo más llamativo de la reflexión sobre las virtudes regias es su decidido carácter secularizador. Don Alonso delimita con rigor el ámbito de la acción de gobierno del príncipe, cuyo norte es el bien común. Por tanto, las virtudes propias del rey serán aquellas que redunden en el bien común. Y estas son justicia, fortaleza de ánimo, liberalidad y magnificencia (las dos primeras son absolutamente necesarias, en tanto que las otras dos no son imprescindibles en el buen príncipe) ${ }^{142}$. Que tal planteo obedecía a profundas convicciones se evidencia en el hecho de que casi dos decenios antes había propuesto análogo catálogo de virtudes regias ${ }^{143}$.

Así, pues, en la cúspide del sistema aretológico regio se sitúa la valentía o fortaleza de ánimo. Si bien Cartagena tiene una concepción plenamente aristotélica de esta virtud, matizada ciertamente desde un punto de vista cristiano por la exégesis tomista ${ }^{144}$, al referirla al rey adquiere un preciso sentido político, en la medida en que se ejercita en la lucha contra los enemigos y la defensa de la integridad territorial del reino ${ }^{145}$. Pues bien, la formulación de la fortitudo en tanto que virtud regia incluida en el Duodenarium constituye el principio organizador del programa iconográfico de la Genealogía de los reyes de España. En efecto, la oposición más productiva del sistema se establece sobre el eje definido por la acción bélica frente al enemigo exterior, que opone el atuendo bélico y la vestimenta pacífica, respectivamente. La cláusula causal que da razón de ambas imágenes incluye la expresión "bellum gerere": en enunciado afirmativo para la primera y en negativo para la segunda.

La condición que se establece para ostentar las armas que simbolizan la fortitudo es que las guerras llevadas a cabo por los reyes sean contra enemigos externos, como demuestra la imagen del rey Silo, que aparece con atuendo pacífico, pues no luchó "cum hostibus", aunque se le asignó un

\footnotetext{
${ }^{142}$ Duodenarium, f. 18 v. b.

${ }^{143} \mathrm{Al}$ glosar su versión del tratado de Séneca De clementia [A. de CARTAGENA (trad.), De la clemençia, BNM, ms. 5568, f. 2 v., al margen].

${ }^{144}$ Tal y como se observa en la definición que de ella ofreciera en su primera obra original: "... vera fortitudo est cum quis sustinet mortem pro optimis rebus, vt quo aliquis se exponit ad mortem in bello pro fide catholica vel salute rei publice vel p(ro)pt(e) r bonum virtutis, ut martires qui pro co(n)fessione fidei mortem fortiter sustinuerunt" (Memoriale virtutum, $\mathrm{f} .19 \mathrm{r}$.): Santo Tomás de Aquino, In X libros Ethicorum ad Nicomachum Expositio, § 538, (Fr. R. M. SPIAZII, ed.), Roma, 1949, p. 153a. Véase L. FERNÁNDEZ GALLARDO, Legitimación monárquica y nobiliaria en el Memoriale virtutum de Alonso de Cartagena (ca. 1425), "Historia. Instituciones. Documentos", 28 (2001), pp. 111-116 y el ceñido comentario a la versión castellana del Memoriale en'Mar CAMPOS SOUTO (ed.), El Memorial de virtudes: la traducción castellana del Memoriale virtutum de Alfonso de Cartagena, Burgos, 2004, pp. 252-279.

145 "Fortitudo superbia(m) hostiu(m) comprimit (et) rei publice fines insectari non sinit" (Duodenarium, f. 19 r. a).
} 
atributo bélico, la espada, por otros respectos: haber sofocado una rebelión interna $^{146}$. El carácter de esa guerra, que a partir de Pelayo no podía ser sino la llevada a cabo contra los moros, queda explícitamente declarado en la representación de Enrique II, a quien se priva de atuendo bélico porque "non tamen cum Arabibus pugnauit" (p. 658). La lucha contra el infiel se erige así en la más alta ocasión en que podía ejercitarse la virtud clave de la realeza. Y no podía ser de otro modo, pues tal guerra revestía carácter de santa ${ }^{147}$ Así, pues, las imágenes construidas sobre el atuendo bélico tienen una inequívoca función celebrativa. La combinación con otros atributos permite establecer una gradación de la excelencia bélica, en cuya cúspide se sitúa la imagen ecuestre, que viene a representar la plenitud de la fortitudo.

El atuendo pacífico, aunque queda opuesto en bloque al bélico, no tiene necesariamente unas connotaciones negativas, simplemente marca su oposición con respecto a la virtud principal de la realeza. De ahí que la definición precisa de los atributos o virtudes de aquellos reyes que no fueron "belicosos" requiriera la adición de otros elementos o gestos. Sin embargo, una variedad del atuendo pacífico, la vestimenta larga, sí que puede aparecer como único rasgo caracterizador, que adquiere precisamente una suerte de preeminencia, en la medida en que es signo de autoridad ${ }^{148}$, aunque no se asocia a una virtud concreta. La justicia en tanto que virtud regia solo aparece mencionada en la imagen de Enrique III, donde tiene su expresión icónica en la espada ${ }^{149}$. En relación con la justicia cabría situar la actividad legisladora de dos monarcas visigodos, que tiene su manifestación icónica en la vestimenta pacífica ${ }^{150}$. Y sin embargo no parece suscitar esta faceta de la realeza gran interés en el prelado burgalés, lo que resulta tanto más paradójico dada su condición de jurista. Así, en la imagen de Alfonso X, a pesar de que se había mencionado en la "historia" su iniciativa legislativa plasmada en las Partidas, la imagen, empero, refiere su vestimenta larga a su condición de

146 “... depingitur in veste pacifica, \& ense in manu prope montes, quia suos rebellantes in montibus subiecit, licet cum hostibus bellum non habuerit" (Anacephaleosis, p. 639).

147 “... cum ex toto uel saltim ad tempus dimissis ciuilib(us) inquietacionibus ad sanctum bellum arabicum expugnacio(n)emg(ue) hostiu(m) fidei forti animo (et) mente catholica properamus..." (Duodenarium, ff. 13 v. b-14 r. a).

${ }^{148}$ Así se indica expresamente en las imágenes de Recaredo y Sancho el Mayor (Anacephaleosis, pp. 628 y 647).

${ }^{149}$ Anacephaleosis, p. 660. Muy significativamente, la imagen que en el Barroco se tenía de este monarca era la de justiciero, como pone de manifiesto una de las más célebres obras de Lope de Vega:

ENRIQUE

«Enrique Justiciero»;

que ya, en lugar del'Tercero,

quiero que este nombre asombre"

[Félix Lope DE VEGA, Peribáñez y el comendador de Ocaña (A. BleCUA, ed.), Madrid, 1987, p. 207]

${ }^{150}$ Imágenes de Leovigildo y Sisenando (Anacephaleosis, pp. 628 y 631). 
erudito $^{151}$. Por otra parte, las restantes virtudes regias, liberalidad, magnificencia y clemencia, carecen de expresión icónica.

El sistema iconográfico se revela solo plenamente productivo en la representación de las virtudes bélicas de la realeza: diríase diseñado exclusivamente para la exaltación del rey guerrero. Y este es uno de los mensajes principales que pretende transmitir la Genealogía: la piedra de toque en la valoración de los reyes es la actividad bélica emprendida contra los enemigos de la fe. Los reyes más preclaros son aquellos que lucharon contra los moros -y entre los visigodos no es casual que sean Recaredo y Sisebuto los titulares de las imágenes con un más decidido carácter celebrativo, pues en las glosas de ambas se hace referencia a sus desvelos guerreros por la fe católica ${ }^{152}$. De este modo, la imagen plástica de la realeza castellana que transmite la Genealogía, moldeada con atributos bélicos, venía a coincidir con la difundida por los sellos reales ${ }^{153}$.

La serie genealógica se cierra con tres imágenes plenamente celebrativas: la de Enrique III, sedente, y las ecuestres de Juan II y Enrique IV. Solo la muerte prematura del primero malogró lo que prometía ser un glorioso reinado por el decidido empeño que mostró este monarca en la lucha contra el moro, cumplidamente consignado en el texto correspondiente ${ }^{154}$. Aun así se le asigna un objeto bélico, la espada, para exaltar la virtud de la justicia, que realza la calidad mayestática de la imagen. Las de los dos últimos reyes podían justificarse por las iniciativas bélicas que ambos tuvieron. El marcado carácter triunfal que poseen -destacado por algunos iluminadores creativos como el del manuscrito $\mathrm{P}^{-}{ }^{155}$ confiere un final apoteósico a la Genealogía, sugiriéndose que en los últimos tres monarcas culminaría la vocación guerrera de la realeza castellana. Las tres últimas imágenes apuntarían, por tanto, a la exaltación de una dinastía que se siente llamada providencialmente para una misión de naturaleza bélica, la recuperación de manos de los infieles del solar otrora perteneciente a la Cristiandad.

Desde esta perspectiva cabría establecer cierta analogía con el programa iconográfico de la serie de retratos ecuestres del Salón del Reino,

${ }^{151}$ Anacephaleosis, p. 655. Aunque en la imagen mencionada de Leovigildo, al hacérsele empuñar una espada, por haber sido "bellicosus", se estaba sugiriendo la superioridad de la faceta legisladora sobre la bélica.

${ }^{152}$ Anacephaleosis, pp. 628 y 630.

${ }^{153}$ Que, para quien los ha estudiado desde la perspectiva de las imágenes del poder que transmiten, ofrecen "essentiellement un message martiạ" (Teófilo RUIZ, L image du pouvoir à travers les sceaux de la monarchie castillane, in Génesis medieval del Estado Moderno. Castilla y Navarra (1250-1370), Valladolid, 1987, p. 220)

${ }^{154}$ Anacephaleosis, p. 660. Cfr. Duodenarium, f. 28 v. a-b.

${ }^{155}$ Quien añadió de su propia minerva las cabezas agarenas bajo las pezuñas del caballo de Enrique IV, motivo iconografico de antiquísima tradición: el triunfo representado por el gobernante victorioso pisoteando al enemigo derrotado (véase sobre éste E.H. GOMBRICH, Gesto ritualizado, pp. 66-68). Se ha interpretado a su vez esta imagen como la de un nuevo Constantino o un nuevo Carlomagno (J. YARZA LUACES, La imagen del rey y la imagen del noble en el siglo XV castellano, in Realidad e imágenes del poder. España a fines de la Edad Media (A. RUCQUOI, coord.), Valladolid, 1988, p. 278). Para las iniciativas bélicas de Enrique IV, véase Ana ECHEVARRÍA ARSUAGA, Enrique IV de Castilla, un rey cruzado, "Espacio, Tiempo y Forma" (Serie III), 17 (2004), pp. 143-156. 
en el palacio del Buen Retiro, que pintó Velázquez, que incluía las tres últimas generaciones de la dinastía entonces reinante: el rey Felipe IV y su esposa, Isabel de Borbón, los reyes antecesores, Felipe III y Margarita de Austria, y el heredero, el príncipe Baltasar Carlos. Ambas series coinciden en la representación ecuestre, en la exhibición de las prendas bélicas de la realeza hispana ${ }^{156}$. Si se tiene en cuenta lo novedoso entonces de la representación ecuestre en España, pues causó admiración por ello el retrato velazqueño de Felipe IV a caballo, hoy perdido, que se exhibió en Madrid, en $1625^{157}$. se evidencia la fina intuición iconográfica de Alonso de Cartagena, quien diríase organiza en el minúsculo espacio de un códice una serie iconográfica análoga a la desarrollada en los muros palaciegos por Velázquez.

Si bien no es cuestión de apurar la relación apuntada entre ambas series de retratos -tres generaciones regias representadas con bélico atavío-, no hay que perder de vista, empero, la difusión que tuvo la Genealogía. Paradoja añadida - solo que aparente- a la señalada al comienzo sobre la fortuna tan adversa que tuvo esta obra en sus inicios viene a ser la difusión que le aguardaba, tanto en los medios cortesanos como en los más amplios círculos eruditos. A diferencia del primer destinatario de la obra completa, Enrique IV, su hermana Isabel mostró interés por esta obra, como pone de manifiesto la presencia de ejemplares tanto en latín como castellano de la Genealogía en su biblioteca ${ }^{158}$. En una ilustración que data del reinado de los Reyes Católicos, el frontispicio de la edición de la Historia Baetica de Carlo Verardi (Basilea, 1494), el "Fernandus Rex Hyspanie" aparece armado y sosteniendo un estandarte, lo cual resulta "extremadamente curioso" para Yarza Luaces ${ }^{159}$; pues bien, la analogía con el dispositivo icónico de la Genealogía resulta aún más significativo. A su vez, ya avanzado el siglo XVI, hacia 1535, se confeccionó un esmerado y lujoso manuscrito de la versión latina para la emperatriz Isabel de Portugal -el denominado N4-, lo que avala la difusión en los círculos cortesanos del programa iconográfico ideado por Alonso de Cartagena ${ }^{160}$.

La relación señalada con la serie de retratos velazqueños justifica plantear la cuestión de si se pretendió una representación veraz de los dos últimos monarcas, sobre todo del dedicatario de la Genealogía. Pues bien, la

\footnotetext{
${ }^{156}$ Véase la penetrante lectura política de este conjunto en Luis DíEz DEL CORRAL, Velázquez, la Monarquía e Italia, Madrid, 1978, pp. 39-55. Aplicable a la Genealogía resulta la siguiente observación de este estudio: “.... una dinastía que en el mismo Salón se exhibía no con atuendo cortesano y ritual (sacro-político o mitológico-político como en el caso de las comentadas pinturas de Rubens), sino con belico dinamismo, tan característico, desde su origen, de la Monarquía Católica" (p. 42). Para el programa iconográfico del Salón del Reino, véase Jonathan BROWN, Velázquez. Pintor y cortesano, Madrid, 1986, pp. 107-109 (interesa especialmente la reconstrucción de los muros oriental y occidental, p. 108).

${ }^{157}$ L. DíEZ DEL CORRAL, ob. cit., pp. 51-52

${ }^{158}$ Elisa RUIZ García, Los libros de Isabel la Católica. Arqueología de un patrimonio escrito, Madrid, 2004, p. 386.

${ }^{159}$ J. YARZA LUACES, Imágenes reales, p. 472.

${ }^{160}$ Véase E. TORMO, ob. cit., pp. 241-256; Ana MUNTADA TORRELlAS, Un ejemplar de la Genealogía de los Reves de España de Alonso de Cartagena en manos de la emperatriz Isabel de Portugal, "Butlletí del Museu Nacional d'Art de Catalunya", 2 (1994), pp. 169-184.
} 
única instrucción icónica que apunta a destacar un rasgo individual se halla precisamente en la representación de Enrique IV. En efecto, a la indicación de la imagen ecuestre, don Alonso especifica que el rey ha de aparecer cabalgando a la jineta, lo cual justifica por ser ésta la modalidad que más utilizaba el monarca ${ }^{161}$. Así, pues, a más de los atributos regios -atuendo bélico y representación ecuestre-, se añadía un elemento que individualizaba al personaje mediante la apelación a una preferencia personal. Y es que las vías para la expresión de la individualidad no se limitaban en el Medievo a la reproducción verista de la fisonomía ${ }^{162}$. Ahora bien, antes que un esfuerzo por captar la individualidad del personaje habrá que ver en esa nota caracterizadora un hábil recurso por captar la simpatía del dedicatario, halagando sus gustos personales. A su vez, no hay que perder de vista que para Alonso de Cartagena esta modalidad ecuestre constituía un signo de la riqueza cultural de España, como indicara en el famoso discurso pronunciado en Basilea en defensa de la precedencia sobre los ingleses ${ }^{163}$. Así, pues, en el momento en que a través del retrato se estaba construyendo la concepción moderna del individuo ${ }^{164}$, el obispo de Burgos se mantiene apegado a una visión estrictamente institucional de los reyes que componen la serie genealógica: solo un tímido indicio de individualización se observa en la imagen del último monarca.

Fecha de recepción del artículo: junio de 2009.

Fecha de aceptación y versión final: diciembre 2009.

161 "Depingitur Enricus in equo armatus , quia succepto sceptro regio confestim bellum Mauris indixis, \& ad modum Ginetari qui [sic] hạc specie equitandi libentius \& frequentius vtitur" (Anacephaleosis, p. 663). En lugar de "qui", habrá que leer "quia", como en AHN cód. 983, f. $45 \mathrm{v}$. b. La predilección de Enrique IV por esta modalidad ecuestre se inserta en la fascinación imitativa de las tendencias orientalizantes de la Granada nazarí, que se extendió en Castilla e invirtió el influjo castellano de la centuria anterior [Emilio GARCÍA GÓMEZ, Ibn Zamrak, el poeta de la Alhambra (siglo XIV), in Cinco poetas musulmanes. Biografías y estudios, Madrid, 1959, pp. 175-180].

${ }^{162}$ Véase al respecto las consideraciones de B. REUDENBACH, loc . cit., pp. 811-812. Sobre la percepción del parecido físico, véanse las siempre sugestivas reflexiones de E. H. GOMBRICH, $L a$ máscara y el rostro: La percepción del parecido fisonómico en la vida y el arte, in La imagen y el ojo, pp. 99-127.

${ }^{163}$ A. de CARTAGENA, De preeminentia, B.N.M., ms. 9262, f. 17 r. Véase el comentario al respecto en L. FERNÁNDEZ GALLARDO, Alonso de Ċartagena, pp. 416-417.

${ }^{164}$ Como se argumenta en Tzvetan TODOROV, Elogio del individuo. Ensayo sobre la pintura flamenca del Renacimiento, Barcelona, 2006. Véase asimismo el clásico ensayo de A. WARBURG, El arte del retrato y la burguesía florentina (1902), in El renacimiento del paganismo, pp. 147175. Con relación a España, no hay que perder de vista que el primer retrato pictórico es el que del Marqués de Santillana hizo Jorge Inglés, terminado precisamente en 1455 (J. YARZA, El pp. 85-86). Carecía, por tanto, don Alonso de sólidos antecedentes para el retrato individualizado, manteniéndose inevitablemente en la tradición del retrato representativo. 
